\title{
GEOPOLITIČNE PERSPEKTIVE SRBSKEGA VPRAŠANJA NA BALKANU
}

\author{
dr. Jernej Zupančič \\ Oddelek za geografijo, Filozofska fakulteta Univerze v Ljubljani \\ Aškerčeva 2, SI- I000 Ljubljana \\ e-mail: jernej.zupancic@ff.uni-lj.si \\ Izvirni znanstveni članek \\ COBISS 1.01 \\ DOI: $10.4312 /$ dela.40.8.133-162
}

\section{Izvleček}

Prispevek obravnava geopolitične dimenzije srbskega vprašanja na Balkanu. Predstavljen je politično-teritorialni razvoj osredja Balkanskega polotoka, v katerem je srbstvo kot etnična in politična kategorija v moderni dobi igralo različno, a vselej pomembno vlogo. Sedaj izstopa srbstvo kot nacija večetnične države in obenem kot narod številčnih manjšin in diaspore, kar povečuje ranljivost srbskega naroda in posredno prispeva h geopolitični labilnosti Balkana.

Ključne besede: Srbi, Srbija, Balkan, geopolitika, politična geografija, narodno vprašanje

\section{GEOPOLITICAL PERSPECTIVES OF SERBIAN QUESTION ONTHE BALKANS}

\begin{abstract}
The article is analyzing the geopolitical dimensions of Serbian ethnic question on the Balkans. The main attention is paid to the political-territorial development of the core of the Balkan space, where the role of Serbs as ethnic as well as political category was different through the whole modern period, but very important. Nowadays, the Serbs are a nation of multi-ethnic country and with many minorities and large diaspora. This situation makes the Serbian nation more vulnerable politically and contributes to the geopolitical liability of the Balkans.
\end{abstract}

Key words: Serbs, Serbia, Balkans, geopolitics, political geography, ethnic question 


\section{UVOD}

Ko je Laffan objavil svoje znano delo 'Srbi - čuvarji mostu' (Laffan, 1989) si verjetno ni predstavljal, da bo le desetletje pozneje namesto 'policista na Balkanu' zrl pred seboj nacijo, ki so jo unitaristična prizadevanja in nacionalizem v jugoslovanskem okviru povsem razdelila, mednarodno osamila, gospodarsko osiromašila in demografsko skrčila. Toda tak je kratek rezime približno dvajsetletne tranzicije Srbov in Srbije, ki je šele po vseh delitvah po skoraj stoletju jugoslovanske ere znova postala država z istim imenom. Opazovanje geopolitične dinamike osredja Balkanskega polotoka in najpomembnejšega domačega igralca v tej strateški regiji - Srbov in Srbije - je zadnji dve desetletji v strokovni in znanstveni literaturi potekalo pretežno skozi prizmo medetničnih konfliktov, ki so le del - in morda bolj posledica kot vzrok - obsežnih in raznolikih tranzicijskih procesov postkomunistične Jugovzhodne Evrope. Pričakovanja, da bodo $\mathrm{v}$ času globalizacije, informatizacije in evropskega povezovanja lahko presegli ozkost nacionalnih pogledov, so se hitro izkazala za popolno iluzijo. Pričelo se je desetletje medetničnih spopadov na široki robni coni med evropskim (sedaj EU) in evrazijskim (Rusija) jedrom. To je sedaj najobsežnejše krizno in postkrizno območje na svetu, ki sega od Balkana prek Jugozahodne in Srednje Azije do Indijske podceline. Jugoslavija, nekoč vzor urejevanja večetnične družbe in zgled federalizma (Seton-Watson, 1980, str. 5), se je sesedala v seriji lokalnih vojn. Namesto vsaj provizoričnega reda se je uveljavil kaos, namesto moči periferija. Med vsemi narodi pokojne federacije so bili edino Srbi, najštevilčnejša ter središčno naseljena etnija, edini, katerih glavni interes je bil ohranitev zveze.

Srbsko vprašanje je nazoren primer usodne povezanosti prepleta politično-teritorialnih sprememb, etničnega in demografskega razvoja ter gospodarske preobrazbe družb. Krize so izjemno razširile obseg perifernih območij in povsem spremenile politično podobo Balkanskega polotoka. V luči teoretičnih geopolitičnih premislekov je pomembno zaporedje: kaj je glavni vzrok, kaj spremljajoči proces, kaj nujna in kaj sprotna posledica? Odgovori na ta vprašanja so pomembni za presojo današnjega položaja in zasnovo bodočih nacionalnih politik na ravni držav in širše.

Balkanski polotok v celoti je sedaj nesporna evropska periferija. Vrsta kazalcev, od gospodarskih in demografskih do socialnih, političnih in kulturnih, kaže na občutne razlike med državami te regije in povprečjem EU - kaj šele primerjaje z najbolj razvitimi in bogatimi družbami evropskega severozahoda. Tako je seštevek BDP vseh držav Zahodnega Balkana za petino manjši kot Romunije, največje države te regije, ta pa obsega komaj dobro polovico moči grškega gospodarstva. Primerjava BDP na prebivalca pokaže še večje razlike znotraj regije (Der neue Fischer Weltalmanach 2014, 2013, str. 524-530) in še bolj na kričeče, skoraj nedosegljive razlike $\mathrm{v}$ primerjavi s povprečjem EU ter $\mathrm{z}$ najbolj razvitimi državami EU (Key figures on Europe 2012, 2012). Podobno izrazito negativni so demografski trendi tudi pri vseh drugih državah, razen Kosova in Makedonije, saj države izstopajo z zelo šibko rodnostjo, povprečno smrtnostjo in očitnim naravnim demografskim nazadovanjem (Sardon, 2001). Za celotno regijo je značilna tudi negativna selitvena bilanca (Bonifazi, Mamolo, 2004). Med ciljnimi območji selitev iz balkanskih 
držav se poleg že uveljavljene Srednje in Zahodne ter Severne Evrope, Severne Amerike in Avstralije javljajo nove, npr. Turčija in bogate arabske države.

Perifernost Balkana je tudi politična, saj so nekatere države (Kosovo, Bosna in Hercegovina) neposredno in posredno pod nadzorom mednarodnih sil in civilnih misij, ali pa so bile krajši čas v bližnji preteklosti (Albanija, Makedonija, Hrvaška). Zaradi hude finančne in nasploh gospodarske krize je Grčija, doslej najmočnejše balkansko gospodarstvo, pod nadzorom in pomočjo evropskih institucij. Srbija - jedro ostanka nekdanje jugoslovanske federacije, demografsko, gospodarsko in vojaško najmočnejše sile Balkana ob koncu 80. let 20. st. (Marković, 2007, str. 19) ${ }^{1}$, je po seriji lokalnih vojn, v katere je bila neposredno in posredno vpletena, doživela mednarodno vojaško intervencijo sil zveze NATO. To dejanje je korenito spremenilo razmerja med regionalnimi silami, demonstriralo pa je tudi prevlado ameriških oziroma zahodnih sil na širšem območju. Rusija se je morala vsaj za nekaj časa umakniti iz tega dela 'vmesne' Evrope. V teh procesih je Balkan kljub izrecni napovedi širjenja EU na to območje - postal tudi tekmovališče evropske in ameriške geopolitike, v katero se posredno vključuje tudi prenovljena gospodarska moč Turčije (Avijucki, 2009). Ta nastopa kot ključni skrbnik muslimanskih družb na Balkanu, računajoč predvsem na svojo ekonomsko moč in kulturni vpliv na spoju evropskega in azijskega prostora (Tunjić, 2010, str. 63).

Posebno pozornost, še posebej v političnogeografskem smislu, moramo nameniti procesom politično-teritorialnega drobljenja, ki je praviloma odraz velike geopolitične dinamike na samem območju in v njegovem strateškem zaledju. Po padcu socialističnih ureditev od leta 1989 dalje je jugoslovanska federacija razpadla (1991) in v dobrem desetletju se je politični zemljevid Balkana korenito spremenil. Skoraj vse države naslednice nekdanje jugoslovanske federacije zaradi mešane etnične sestave prebivalstva niso mogle uresničiti enega glavnih idealov evropskih nacionalizmov - etnično homogene države. Zato je sledilo burno desetletje spopadov in oblikovanja začasnih paradržav - teritorijev s posebnimi geografskimi značilnostmi in logiko vojne ekonomije. Vojne so zaznamovale ta območja ne le z neposredno in posredno škodo, temveč tudi z oblikovanjem poznejših prehodnih statusov, kakršni so npr. enklave in demografsko izpraznjena območja.

V kontekst razprave o perifernosti Balkana sodi prav srbsko vprašanje. Ta perifernost je dvojna: najprej v odnosu med zunanjimi silami in Balkanom kot celoto in drugič v odnosu med srbskim jedrom in srbskimi periferijami. Srbstvo ima kot etnična in politična kategorija obe vrsti izkušenj. Zgodovinska izkušnja nekdanje moči ponekod še sedaj hrani nacionalne mitologije, obenem pa je infrastrukturna zapuščina jedra nekdanje jugoslovanske federacije, ki je sedaj na srbskem ozemlju, tej državi v precejšnje breme. $\mathrm{V}$ tem pogledu je srbsko vprašanje povsem primerljivo s situacijo npr. Rusov in Rusije po razpadu Sovjetske zveze ali pa z nemškim in madžarskim vprašanjem po razkroju Avstro-Ogrske leta 1918. Razkroj večnacionalnih držav pušča etničnim jedrom nekdanjih vodilnih etnij vrsto manjšin; to pa je okoliščina, ki se ji morajo šele prilagoditi - seveda ob travmatični izkušnji doživetja političnega poraza. Srbi so se kot jedro nekdanje

1 Jugoslovanska ljudska armada (JLA) naj bi bila takrat po nekaterih prepričanjih tretja, četrta ali peta najmočnejša armada v Evropi. Avtor ugotavlja, da to ne drži po nobenem izmed vojaških kriterijev glede materialnih in človeških virov. To je bil zgolj eden od mitov, ki je hranil jugoslovansko nacionalno samozavest. 
Jugoslavije v fazi njenega razkroja znašli v položaju zmanjševanja teritorija, moči in vpliva, z neke vrste političnim porazom in s tem povezano travmo, pozneje pa še z močnim mednarodnim pritiskom, ki je - kot že večkrat prej v moderni dobi - bistveno določal potek mednarodnih političnih meja na Balkanu. Med vsemi narodi nekdanje Jugoslavije so pristali v situaciji izrazite teritorialne razdeljenosti in so - vsaj kar zadeva primarne cilje balkanskih nacionalizmov - skoraj zanesljivo najbolj prikrajšani.

\section{METODOLOŠKA IZHODIŠČA}

Prispevek prinaša rezultate večletnega interdisciplinarnega raziskovanja narodnega vprašanja na Balkanu. Ta združuje presojo politično-teritorialnega razvoja, etnogeneze posameznih narodov in analizo širšega geopolitičnega konteksta. Metodološko gledano gre za uporabo primerjalno-interpretativne metode, pri čemer politično-teritorialne spremembe določenih ozemelj analiziramo interpretativno v luči vpliva notranjih in zunanjih sil (funkcijski vidik), geografske strukture (strukturni vidik) ter oblik teritorialne in politične organiziranosti (morfološki vidik). Na podoben način so bili že objavljeni izsledki raziskovanj makedonskega (Zupančič, 2006), albanskega (Zupančič, 2008) in črnogorskega narodnega vprašanja (Zupančič, 2010). Iz vseh poročil veje dejstvo, da imamo v celotni regiji opraviti s precej zapleteno etnično, jezikovno in versko sestavo prebivalstva ter prevladujoč, neposreden in posreden vpliv tujih (zunanjih) sil na oblikovanje državnih političnih meja, medtem ko so strukturne in etnične procese krojile predvsem domače sile. Predpostavljamo, da je tudi pri srbskem vprašanju podobno. Vendar lahko že uvodoma v to domnevo nekoliko dvomimo, saj je bil srbski etnos sorazmerno številčnejši in vsaj v jugoslovanskem obdobju v več ozirih dominanten. Etnogenezi Srbov se moramo zaradi omejenega prostora žal odreči.

V predhodnih študijah je bilo že izpostavljeno vprašanje racionalnosti konfliktov. Niso namreč redke teze o 'iracionalnih' agresivnih nacionalnih ideologijah, kakor omenja Mazower v epilogu svoje knjige (Mazower, 2002, str. 387-394), a je v luči geopolitične presoje silno dvomljivo, ali je to res. Lahko postavimo hipotezo, da so tako stari kot novi konflikti dejansko sledili povsem stvarnim, racionalnim interesom in ciljem. Etnično pripadnost so pogosto prikrojevali strateškim potrebam. Medetnični konflikti, ki izhajajo iz nasprotij med identitetami (Riedel, 2005, str. 306-308), v luči te presoje niso več (kot so videti sprva) iracionalni anahronizmi Balkana, temveč načrtni poskusi doseganja nacionalnih geopolitik, enakih kot jih je še dolgo v 20. st. Evropa poznala kot pravilo in ne kot izjemo.

\section{DEMOGRAFSKE,TERITORIALNE IN POLITIČNE RAZSEŽNOSTI SRBSTVA}

Politično-teritorialne spremembe ter selitveni tokovi so postopoma oblikovali zapleteno situacijo evropskih narodov. Nacije, manjšine in diaspora predstavljajo povprečno realnost evropskih narodov, tudi Srbov. Srbi sodijo v evropskem okviru med srednje številčne. Po nekaterih ocenah jih je okrog 7,9 mil. pripadnikov (Pan, Pfeil, 2000, str. 11) ${ }^{2}$,

2 V tej oceni diaspora ni vključena. 
najvišje ocene pa krepko presegajo 10 mil. Pri tem se ocenjuje, da živi zunaj Srbije in Republike Srbske v Bosni in Hercegovini okrog 3,5 mil. oseb srbskega porekla (Srpska dijaspora, 2013). Razlike ne izhajajo le iz različnih popisnih in ocenjevalnih kriterijev, temveč v nekaterih primerih tudi iz različnih definicij srbske narodne pripadnosti.

Slika 1: Srbski poselitveni prostor glede na oblike politične organiziranosti

Figure 1: The Serbian ethnic space by forms of political organization

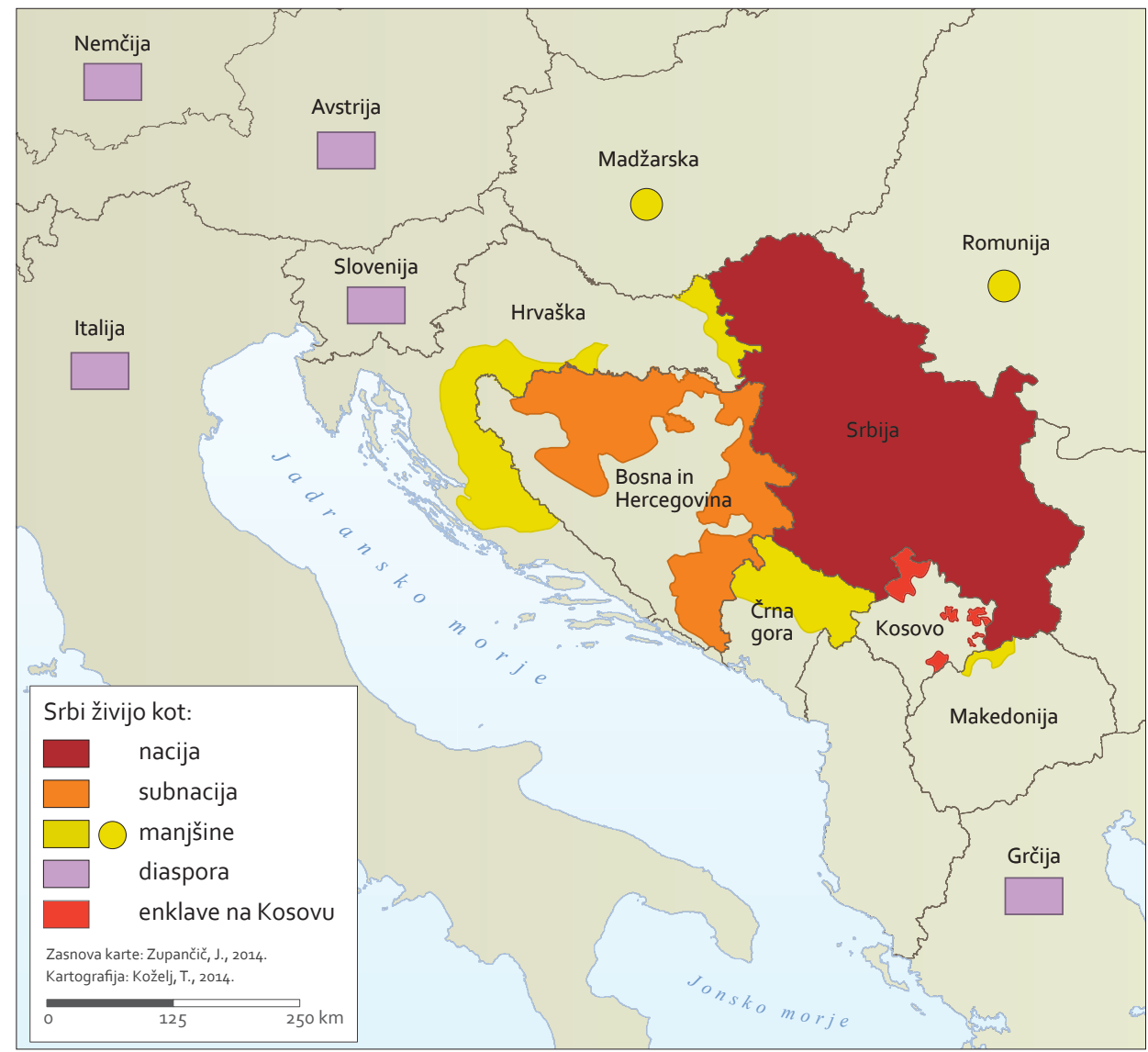

Politično-teritorialno jedro srbskega naroda je Srbija, ki ima v milijonski prestolnici Beograd nesporno politično, gospodarsko in kulturno središče. V srbski nacionalni državi živi le dobra polovica (okrog 6 mil.) vseh Srbov. Dobra desetina (ali približno 1,5 mil.) jih živi v Bosni in Hercegovini, večinoma v okviru Republike Srbske in torej v položaju sub-nacije. Le nekaj odstotkov (nekaj manj kot 0,5 mil.) jih je naseljenih v obliki tradicionalnih manjšin. Stare teritorialne (ali tudi klasične, zgodovinske) srbske manjšine so na Hrvaškem in Madžarskem, v Romuniji, Bolgariji, Makedoniji, Črni gori in Albaniji. 
Poseben položaj imajo Srbi na Kosovu. Ostali, po različnih ocenah od 1,8 mil. do 3,5 ali celo 4 mil., pa so predstavniki raznolike srbske diaspore po svetu, navzoče v okrog sto državah (Srpska dijaspora, 2013).

Srbi so narod več držav, ne le v preseku zgodovinskih usod, temveč tudi v sedanjosti. Poleg Srbije kot naslednice Zvezne republike Jugoslavije (ZRJ) je v Bosni in Hercegovini ostala srbska entiteta (Republika Srbska). Na Kosovu, nekdanjem ustavnem ozemlju Srbije, kjer po Ahtisaarijevem načrtu (Report of the special envoy ..., 2007, str. 3-9) ${ }^{3}$ kot ključnem neposrednem aktu za uveljavitev neodvisnosti Kosova, velja konstitutivnost Srbov na tem multietničnem teritoriju. Številčna srbska skupnost je tudi v Črni gori, ki je bila vse od podgoriške skupščine leta 1918 v teritorialno-politični povezavi s Srbijo, nekateri pa jo - tako zgodovinsko kakor aktualno - kratko malo štejejo za drugo srbsko državo, čeprav ima bogato politično zgodovino in vrsto etničnih posebnosti (Zupančič, 2010). Ta politična razdeljenost Srbov je odraz razdiralnih političnih procesov, ki jih je prostor osrednjega dela Balkana doživel ob prelomu tisočletja.

Srbi niso edini narod na Balkanu, ki se sedaj nahajajo v položaju večdržavnosti. Tako žive Albanci v dveh državah (Albanija in Kosovo), poleg tega pa so močneje navzoči tudi v Makedoniji, kjer jim po ohridskem sporazumu iz leta 2001 pripadajo precejšnje bonitete v državni upravi. Grki žive prav tako v dveh državah (Grčija in Ciper), enako tudi Romuni (v Romuniji in Moldaviji; Zupančič, 2009, str. 128-129). Take okoliščine predstavljajo nekoliko povečano tveganje združevalnih poskusov.

Drugo obliko politične organiziranosti Srbov predstavlja Republika Srbska, entiteta v okviru Bosne in Hercegovine. Po mednarodnem priznanju te države in sledeči štiriletni državljanski vojni so ozemlja pod nadzorom srbskih sil po sporazumu v Daytonu (november 1995) postala posebno ozemlje - entiteta, kar je posebnost v svetovnem okviru. Bosna in Hercegovina tako nominalno ni federacija, ampak de facto dvostopenjska asimetrična federativna država, nad politično usodo katere še vedno bdijo mednarodne sile, sedaj (2013) večinoma le politične in manj vojaške. Poleg dveh entitet, torej unitarne Republike Srbske in bošnjaško-hrvaške federacije (Federacija Bosna in Hercegovina), ki jo sestavlja enajst kantonov, večinoma urejenih glede na merila etnične homogenosti in manj glede na druge oblike povezanosti, premore ta država še zvezni distrikt Brčko. Kantonalna ureditev je rezultat številnih kompromisov (Burg, Shoup, 1999) in dejansko v precejšnji meri tudi odraz razmerja sil od srede leta 1995 dalje do pogajanj v Daytonu. To se kaže zlasti pri nekaterih pojavih etničnih enklav, ki pa so bile predvsem odraz vojaških razmerij in le skromno ustrezajo predvojni etnični razporeditvi prebivalstva.

Srbske manjšine se nahajajo v sosednjih državah Srbije in predstavljajo del sklenjene srbske poselitve, vendar ne povsem dosledno. Ker je opazen del teh skupnosti nastal s kolonizacijo in begunstvom, so se oblikovali tudi bolj ali manj izraziti etnični otoki na Madžarskem, v Romuniji in posebej na Hrvaškem. Srbska skupnost na Hrvaškem je nekoliko posebna tudi zaradi stare teritorialne organiziranosti: t. i. 'vojne krajine'. To je bila oblika frontiera, organizirana s strani habsburškega cesarstva, srbski živelj pa je bil v njej

3 Analiza razmer in podroben načrt sta podana v dokumentu Comprehensive proposal for the Kosovo status settlement, 2007, 61 str. 
najpogostejši, a še zdaleč ne edini etnični element. V procesu razpadanja jugoslovanske federacije in oblikovanja novih nacionalnih držav pa so 'krajine' dobile posebno obliko. Postale so uporniški teritoriji (po obliki dejansko paradržave) s hrvaškega in marionetne države s srbskega etnocentričnega zornega kota. Imele so vojaško upravo in bile pod močnim vplivom jugoslovanske vojske in srbske politike Slobodana Miloševića (Pirjevec, 2003, str. 65-74). Takšni pojavi so značilna in nikakor ne izjemna, posebna podoba kriznih in postkriznih območij. Njihov pojav dokazuje robnost geopolitičnih enot, saj je prav 'rob' predmet tekmovalnih odnosov in celo spopadov, v katerih periodično nastajajo začasna paradržavna ozemlja.

Tretjo obliko teritorialne organiziranosti predstavljajo enklave, ozemlja z določenimi merami notranje avtonomnosti, po ustroju in politični preteklosti pa so predvsem rezultat novejših združevanj prebivalstva po etnični pripadnosti. Pojavljale so se v Bosni in Hercegovini (večinoma so bile bošnjaške), zelo značilne so tudi za Kosovo. Tu govorimo predvsem o srbskih enklavah, med katerimi je največja Kosovska Mitrovica na severu, ki se edina teritorialno stika s srbskim državnim ozemljem. Srbske enklave na Kosovu so posledica dolgotrajnih medetničnih sporov na južnem robu srbskega etničnega in političnega prostora.

Srbska diaspora je zelo številčna in raznolika tako po časovni kakor po geografski določenosti; po nekaterih ocenah naj bi bilo v diaspori blizu 4 milijone Srbov (Palić, 2011). Stare srbske diaspore so nastajale kot rezultat begunstva izpod turških oblasti (tak primer so tudi maloštevilčne stare uskoške naselbine v Sloveniji; Komac in sod., 2012), deloma pa kot rezultat gospodarske privlačnosti jeder habsburške monarhije. Tako so se Srbi priseljevali na Dunaj, v Budimpešto in njeno okolico, v Prago ter Trst. Velika večina srbske diaspore pa je novejšega nastanka. Nastajala je podobno kot druge etnične diaspore v evropskih državah, Ameriki in Avstraliji od druge polovice 19. st. dalje. V Evropi so številčne srbske skupnosti prisotne predvsem v državah Srednje (Švica, Nemčija, Avstrija) in Zahodne Evrope (države Beneluksa, Francija, Velika Britanija) ter v Skandinaviji (večinoma na Švedskem). Zelo močna je srbska skupnost v ZDA in Kanadi, Avstraliji, Južnoafriški republiki ter na Novi Zelandiji.

Pri srbskem narodnem vprašanju gre za etnopolitične razsežnosti naroda, ki poleg pojava večdržavnosti in sorazmerno številčnih teritorialnih in razpršenih manjšin obsega tudi velik delež pripadnikov v diaspori. To je značilno za več narodov na Balkanskem polotoku in odraža njihovo veliko politično-teritorialno in selitveno dinamiko. Vendar lahko le pri redko kateri drugi etnični skupnosti ugotavljamo tako velika nihanja v geopolitični konotaciji njihovega ozemlja in s tem tudi skupnosti same. Te okoliščine se kažejo tudi v znanstveni literaturi o tem vprašanju, saj se ocene vloge Srbov na Balkanu gibljejo od zelo prizanesljivih starejših opredelitev, ko je bilo srbstvo zamišljeno kot 'jedro' jugoslovanskega geopolitičnega prostora, do prevladujočih polemičnih in kritičnih tonov v zadnjih dveh desetletjih, v katerih so bili Srbi večinoma prepoznani kot glavni krivci za serijo lokalnih vojn in njihovih posledic. Prednost širše geopolitične presoje je prav v naravnanosti, da na podlagi primerjave časovno-prostorske dimenzije prepozna ključne elemente sodobnih konfrontacij, saj je očitno, da klasični aksiomi varnostnih politik v kontekstu sodobnih kriznih območij preprosto ne zdržijo več. 
Preglednica 1: Srbsko prebivalstvo po državah

Table 1: Serbian population by countries

\begin{tabular}{|c|c|c|c|}
\hline Država & $\begin{array}{l}\text { Število Srbov po } \\
\text { popisih in uradnih } \\
\text { ocenah }\end{array}$ & $\begin{array}{c}\text { Število Srbov po } \\
\text { ocenah }\end{array}$ & $\begin{array}{l}\text { Status srbskega } \\
\text { prebivalstva }\end{array}$ \\
\hline Srbija & 5.988 .150 & & nacija \\
\hline Bosna in Hercegovina & $1.437 .500^{1}$ & & $\begin{array}{l}\text { nacija } v \text { entiteti } \\
\text { Republika Srbska }\end{array}$ \\
\hline Kosovo & $25.532^{2}$ & 140.000 & $\begin{array}{l}\text { formalno konstitutivni } \\
\text { narod, dejansko } \\
\text { manjšina v enklavah }\end{array}$ \\
\hline Hrvaška & $186.633^{3}$ & & manjšina \\
\hline Črna gora & $178.110^{4}$ & & manjšina \\
\hline Makedonija & 36.000 & & manjšina \\
\hline Madžarska & 7210 & & manjšina \\
\hline Romunija & 18.076 & $22.500^{5}$ & manjšina \\
\hline Bolgarija & & $2000^{6}$ & manjšina \\
\hline Albanija & & $25.000^{7}$ & manjšina \\
\hline Grčija & & $15.000^{8}$ & diaspora \\
\hline Slovenija & 38.964 & $50.000^{9}$ & diaspora \\
\hline Nemčija & 560.000 & $800.000^{10}$ & diaspora \\
\hline Avstrija & $177.320^{11}$ & 350.000 & diaspora \\
\hline Italija & & $100.000^{12}$ & diaspora \\
\hline Švica & 120.000 & 196.000 & diaspora \\
\hline Nizozemska & & 40.000 & diaspora \\
\hline Belgija & & 20.000 & diaspora \\
\hline Luksemburg & & 7581 & diaspora \\
\hline Francija & & 120.000 & diaspora \\
\hline Velika Britanija & & 70.000 & diaspora \\
\hline Švedska & & $60.000^{13}$ & diaspora \\
\hline ZDA & 187.739 & 1.000 .000 & diaspora \\
\hline Kanada & 80.320 & 400.000 & diaspora \\
\hline Avstralija & 69.544 & 200.000 & diaspora \\
\hline
\end{tabular}

Viri podatkov $v$ tabeli so navedeni $v$ seznamu virov in literature. 


\section{Opombe/Comments:}

1 Večina jih živi na ozemlju Republike Srbske.

2 Popis 2011 je zaradi bojkota večine srbskega prebivalstva zabeležil le 25.532 pripadnikov. Po popisu leta 1991 jih je bilo še 194.190.

3 Po popisu leta 2001 jih je bilo še okrog 206.000, pred razpadom Jugoslavije (popis 1991) več kot 580.000 in so sestavljali dobrih $12 \%$ prebivalstva.

4 Ob popisu leta 2011 je bilo po kriteriju maternega jezika 265.895 oseb s srbskim maternim jezikom oziroma skoraj $43 \%$.

5 Ob popisu leta 2001 jih je bilo po kriteriju maternega jezika 16.805. Po drugih navedbah naj bi jih bilo več kot 22.000 (Cerović, 2005).

6 Statistični popisi v Bolgariji Srbov ne izdvajajo posebej.

7 Albanski popis 2011 ne loči Srbov in Črnogorcev, a tudi sicer je slednjih le 2000. Ocene so precej višje, saj naj bi bila manjšina pod močnimi pritiski (Srbi u Albaniji..., 1998).

8 Ocenjeno število precej variira zaradi velikega števila sezonskih delavcev v turizmu (Srpska dijaspora, 2013).

9 (Komac in sod., 2012). Popis leta 2011 narodne pripadnosti ni več ugotavljal.

$10 V$ Nemčiji popisov ne izvajajo. Ocene so dokaj različne, od nižjih (Serben in Deutschland, 2013) do dokaj visokih - 800.000 (Srpska dijaspora, 2013).

11 Popis leta 2011 jezikovne pripadnosti ni več ugotavljal.

12 Za to in večino navedenih držav so ocene povzete po spletnem portalu Srpska dijaspora (2013).

13 Popis leta 2005 ugotavlja državo rojstva; po tem kriteriju je bilo na Švedskem 74.032 oseb iz ZR Jugoslavije. Po letu 1960 izvaja Švedska popise na 5 let in ne na 10 kot je praksa drugod. Do leta 1990 je bil podlaga popisov register prebivalstva, popis leta 2005 je v celoti temeljil na registru. To prakso je v nekoliko spremenjeni obliki prevzela tudi Slovenija, Nemčija npr. popisov nima in 'zaupa' registrom.

\section{POLITIČNO-TERITORIALNI RAZVOJ SRBSKIH OZEMELJ}

Pojem srbskega etničnega ozemlja ni tako jasen kot pri večini drugih narodov in etnij Balkanskega polotoka. Težava izhaja iz različnih opredelitev pripadnosti srbskemu narodu ter očitno zelo široke cone etnične pomešanosti, do katere je prihajalo že v preteklosti tako zaradi množičnih selitev kakor etnokulturne konverzije ${ }^{4}-$ kar pa je bil precej pogost pojav. Drugi razlog tiči v politični percepciji nacionalnega ozemlja, ki so ga v drugi polovici 20. st. opredeljevali bolj kot pravnoposestno kategorijo in se manj ozirali na etnične in širše kulturne značilnosti na njem živečega prebivalstva. Poleg tega se izpostavlja tudi vprašanje ključnega merila narodne pripadnosti. V razpravah o etničnosti se najpogosteje omenja jezik, vendar je ta sedaj pogosto predvsem sredstvo

4 Pojav etnične konverzije ni tako redek pojav. V Jugoslaviji so se popisne kategorije npr. 'Muslimanov', 'Jugoslovanov' in še nekaterih drugih - še posebej regionalnih identitet - popisovale od popisa do popisa različno. Tako so bile iste osebe ob različnih popisih opredeljene različno, deloma zaradi novih popisnih opredelitev, deloma zaradi prilagajanja posameznikov novim družbenim in političnim razmeram. Svež primer te vrste je nihanje števila in deleža Srbov v Črni gori. 
in medij sporazumevanja, mnogo manj pa definira kulturo naroda. Med narodi so precejšnje razlike glede pomena in vloge narodnega jezika. Medtem ko je npr. pri Slovencih povezanost jezika (slovenščine) in narodnega (samo)opredeljevanja v zelo visoki korelaciji, v srbskem primeru ni nujno vedno tako. Široko območje med Istro na zahodu in Timoško krajino na vzhodu je še pred tremi desetletji sestavljalo t. i. srbohrvaški (ali tudi hrvaško-srbski) jezikovni prostor, na katerem je jezik - kljub nekaterim pisnim, glasovnim in kulturnim razlikam - predstavljal enotno sredstvo komunikacije, tako da je bilo sporazumevanje $\mathrm{v}$ tem prostoru mogoče brez prevajanja. Z održavljanjem nekdanjih republik minule jugoslovanske federacije pa so se osamosvojili tudi jeziki in - kar morda zveni paradoksalno - postali jezikovno suvereni šele po vzpostavitvi politične suverenosti . Hrvaški, srbski, bošnjaški in črnogorski jezik so tako merodajni gradniki etnične samobitnosti narodov, zaradi načrtno ločenega razvoja pa postajajo čedalje bolj različni med seboj. Ob tem ne gre prezreti, da je srbski jezik nacionalni identifikator srbstva in to kljub velikim narečnim razlikam znotraj srbskega jezikovnega telesa in ne glede na politične okoliščine, v katerih živi.

\section{I. Oblikovanje srbskih srednjeveških držav}

Pričetek srbskega teritorialnega razvoja lahko postavimo v obdobje po valu selitev ob koncu rimskega obdobja, časovno pa v začetek 7. st. (Srbija, 1998, str. 222). Datacija ni natančna, a tudi ni pomembna, saj sta $v$ času po razpadu rimskega imperija sledili vsaj dve stoletji političnega kaosa brez oblikovanja večjih državnih tvorb. Politično jedro tiste dobe je bil Bizanc, nekdanji Konstantinopel, ki je obvladoval bogato zaledje egejskih in črnomorskih obal s staro grško urbano tradicijo. Selitveni valovi so oslabili gorato zaledje v notranjosti Balkana in s tem omogočili precej neoviran razvoj novih jeder politične moči na tem območju. Ni naključje, da so se na ozemlju od vzhodne jadranske obale do Zahodne Morave razvile številne državne tvorbe: Zahumlje, Travunija, Neretvanska kneževina, Duklja in Raška. Slednja je imela prednost zaradi zavarovanega gorskega oboda, kar je postalo pomembno zlasti po razširitvi srednjeveške Bolgarije za Simeona (913-927; Lalkov in sod., 2000, str. 24). Srbski knez Časlav (927-950) se je z bizantinsko pomočjo otresel bolgarske politične nadvlade in takratno Raško razširil proti Jadranu. Kratkotrajno makedonsko fazo (1000-1014) za carja Samuela je nasledil ponovni bizantinski vpliv in z njim povezano širjenje krščanstva.

Oboje je imelo pozneje izjemen pomen, saj je bil ta prostor predvsem v domeni širjenja bizantinske politične, gospodarske in verske kulture, kar je definiralo srbstvo kot poznejšo etnično kategorijo. Toda politično jedro ni bila več gorata Raška, pač pa Duklja v današnji Črni gori (Zgodovina narodov Jugoslavije1, 1953, str. 234-238). Ta zgodovinski dogodek se v nacionalni ikonografiji rado postavlja kot instrument enotnosti črnogorstva in srbstva. Duklja je za relativno neoviran politični razvoj razpolagala z dvema ključnima prednostima: primerno razdaljo od glavnih jeder tistega časa (in s tem varnost pred njimi) ter pomorski položaj v južnem delu Jadrana. Verjetno je gospodarska moč prispevala k povečevanju politične moči Duklje in Zete za Bodina 
(1082-1101) in njuno širjenje v gorato zaledje t. i. Starega Vlaha ${ }^{5}$. To obdobje je zaznamoval cerkveni razkol (t. i. velika shizma, 1054). Duklja oziroma Zeta je bila na meji teh vplivov, kar pa je treba presojati tudi v luči oblikovanja močne madžarske države v Podonavju ter samostojnosti srednjeveških držav Hrvaške in Bosne.

Slabljenje bizantinske moči so izkoristili župani Raške. Pod Štefanom Nemanjo (11681196) sta sledila silovit vzpon Raške in ozemeljska širitev proti zahodu v Bosno, proti jugu na Kosovo in v Dukljo ter Zeto in proti Pomoravju na vzhodu, kjer se je Raška razširila na račun bolgarskega carstva. Njegovi nasledniki so državo utrdili, tako da je postala vodilna sila na Balkanu. K temu je pomembno prispevala tudi odločitev za pravoslavje, saj je to omogočilo srbskim vladarjem tudi vzpostavitev cerkvene in ne le politične suverenosti. Bizantinsko carstvo je hromelo zaradi vzpona srednjeveških držav na Balkanskem polotoku, še bolj pa zaradi konkurence nove vojaške sile v Mali Aziji - turške države. Slabili so jo tudi prehodi križarjev, ki so z zelo omejenimi uspehi skušali zaustavljati širjenje Arabcev in islama proti Evropi. S širjenjem turške države je slabela gospodarska moč Bizanca, kar je nekaj časa ustrezalo zlasti balkanskim fevdalnim državam (Ostrogorski, 1961, str. 469494). Srbija je v tem času dosegla ne le največji teritorialni obseg, saj je obsegala celotno ozemlje med Donavo na severu in obalami Egejskega morja na jugu, vse do Korintskega zaliva (Srbija, 1998, str. 223). Na zahod je segala v današnjo vzhodno Hercegovino. Politično, versko in gospodarsko jedro srednjeveške srbske države je bilo na današnjem Kosovu, prav tako tudi njeno geografsko središče. $V$ to dobo sodi tudi razcvet samostanov, saj so bile notranjepolitične gospodarske okoliščine za to nadvse ugodne. Ker so posamezni fevdalci povečevali svojo moč na račun slabljenja moči carja, so to dokazovali tudi z bogatimi nadarbinami samostanom (Boeckh, 2009, str. 17-19 in 22), ki so bili sicer središča umetnosti, kulture in pismenstva $\mathrm{v}$ tistem času. Ta čas srbske srednjeveške slave ima $\mathrm{v}$ narodnem spominu izjemno mesto, saj predstavlja hranilo vseh poznejših nacionalnih mitologij.

Osamosvajanje fevdalnih velikašev je imelo za državo predvidljive posledice, saj je v kontekstu celotnega dogajanja v manj kot stoletju pripeljalo do razkroja nemanjiške Srbije. Razdrobljenost je namreč koristila nasprotnikom, turški sili, ki si je po naglih osvajanjih Male Azije kot ključno strateško smer izbrala Balkanski polotok. Toda oslabljene so bile tudi druge države, zato je sklicevanje na srbsko neenotnost kot ključno strateško napako morda pretirano in bolj služi heroizmu v nacionalnih ikonografijah balkanskih držav kot pa resni presoji (Judah, 2009, str. 29-34), kljub dejstvu, da je neenotnost dejansko pokopala veličino Lazarjevega carstva. Toda ali bi mogla Srbija ob ostalih krščanskih branikih zamejiti turški ekspanzionizem? (Judah, 2009, str. 38-39). Turška država je bila tedaj v silovitem vzponu in je imela, primerjalno gledano, vrsto prednosti, tako materialnih kakor človeških (Kennedy, 2002), zato je usodnost kosovske epizode za širši balkanski ali kar evropski kontekst verjetno pretirana. Srbske despotovine je bilo konec nekaj več kot pol stoletja pozneje s turško zasedbo Smedereva (Srbija, 1998, str. 223).

5 Vlahi so staroselsko romanizirano prebivalstvo Balkanskega polotoka, ki se je po selitvenem valu slovanskih ljudstev ter politične prevlade bizantinske države umikalo v gorata zaledja in dolgo ohranilo nomadski in polnomadski značaj z živinorejo kot ključno gospodarsko panogo. Imenovanje 'vlaških' pokrajin tako v sedanji Romuniji kakor npr. v Starem Vlahu, ki obroblja predele Raške, je odraz sorazmerno velike gostote tega prebivalstva $\mathrm{v}$ preteklosti. Na Balkanu je takih toponimov precej. 


\subsection{Srbija v okviru turškega imperija}

Turška (osmanska) oblast je ukinila politično, ne pa povsem tudi verske oblasti. Leta 1557 obnovljena vrhovna cerkvena oblast pod patriarhijo v Peći je predstavljala versko središče vseh Srbov, ne glede na politične okoliščine. S tem se je krepila vloga pravoslavne cerkve kot verske, kulturne in tudi politične enotnosti. Peć je postal simbolno jedro srbstva $\mathrm{v}$ času, ko politično-gospodarskega jedra preprosto ni bilo.

Ozemlja, ki so nekoč pripadala srbski carski kroni, so doživljala različno usodo. Južne pokrajine so zapolnjevali turški kolonisti in islamizirano prebivalstvo, še posebej Albanci, čeprav so se v goratih predelih tudi sami še dolgo upirali Turkom. Del srbskega prebivalstva se je selil na sever čez Donavo in Savo, na zunanje robove turškega imperija. Uskoštvo je postalo politična kategorija, ki je kapilarno zasedala izpraznjeni prostor v sosedstvu, ter sčasoma, predvsem pod avstrijskim in madžarskim vplivom, oblikovala pravi frontier ${ }^{6}$, obrambno ozemlje, ter na njem vršilo vojaško službo. To so bile poznejše vojne krajine, povsem specifično organizirana ozemlja. Kolonizacija je primarno upoštevala varnostne (za navzoče prebivalstvo) in obrambne vidike (za potrebe zalednih držav), strukturno pa je oblikovala vrsto obrambnih naselij ter postojank. Srbsko prebivalstvo je v nekaterih delih vojne krajine povsem prevladalo, mdr. v Liki, Krbavi, Kordunu, severni Dalmaciji in obsavskih predelih v Slavoniji (Boeckh, 2009, str. 37-39).

Stopnjevanje turškega nasilja ali pa zgolj strah pred njim je v begunstvo potiskalo valove srbskega prebivalstva posebno od 17. st. dalje. Turška uprava je iz nekoč učinkovite in čvrste prešla $\mathrm{v}$ fazo upravnega kaosa. Ker se je v tistem obdobju močno okrepila podonavska avstrijska monarhija in pričela pritiskati na otomanska ozemlja, je to še spodbudilo upore srbskega življa proti turški oblasti. Zaradi razmerja sil pa so uporniki pogosto postali še večje žrtve. Upor leta 1689 je ob umiku avstrijske vojske postal srbska katastrofa, ki so jo omilili s številčnim eksodusom vsaj 40.000 prebivalcev z današnjega Kosova čez Donavo in Savo na precej prazna območja Panonske nižine (Laffan, 1989, str. 26-31). Naselili so se vse do Budimpešte in še severneje, predvsem pa na območju Srema, Bačke in Banata. Ta nova jedra srbske naselitve so okrepili še naslednji manjši valovi srbskih beguncev.

Ko je avstrijski cesar s patentom podelil posvetno in cerkveno oblast patriarhu, so s tem nastali pogoji za oblikovanje Srbske Vojvodine kot posebnega ozemlja znotraj Avstrije. Podobno kot krajine na zahodu je bila tudi to vojaško-ekonomska celota, zaradi obsega in pomena pa je pozneje postala eno izmed jeder srbskega nacionalnega preporoda (Ćorović, 2001). Srbi pri kolonizaciji niso bili edino prebivalstvo, saj je bil prostor spodnjega dela Panonske nižine zaradi preteklih spopadov in manj ugodnih naravnih razmer (obsežna močvirja) precej prazen. Sledilo je nekaj desetletij intenzivne kolonizacije tega območja, in sicer s kolonisti skoraj dobesedno 'z vseh vetrov'. Veliko je bilo tudi Čehov, Slovakov, predvsem pa Nemcev, posebej v Banatu (Sepp, 1983). Današnja izjemno pestra etnična sestava Vojvodine je posledica množične kolonizacije ozemlja zaradi varnostnih in strateških razlogov. S tem je prostor sedanje Vojvodine in romunskega Banata dobil zelo pisano etnično podobo (Klemenčič, Zupančič, 2004).

6 Frontier je v politični geografiji splošni termin, ki označuje obmejni pas s primarno obrambnim namenom. Taka ozemlja so imela posebno upravo, prebivalci pa posebne pravice in seveda dolžnost obrambe. 
Učinkovitost vojvodinskega frontiera je zanesljivo spodbujala odpor srbskega prebivalstva pod turško upravo. Beograjski pašaluk je bil najbližji, gosto naseljen in zaradi robnega položaja znotraj turške države močno izpostavljen represalijam, gospodarsko pa je zaradi tega hiral. Toda hirala je tudi Turčija, ki jo je dodatno načenjala Rusija, rastoča evrazijska velesila, ki je želela prek njenega ozemlja doseči ugodnejša prometno-strateška razmerja. Balkanski narodi, tedaj že osveščeni z idejami nacionalnih preporodov v Srednji in Zahodni Evropi, so iskali nova zavezništva. Od konca 18. st. dalje je sledilo intenzivno obdobje narodne emancipacije, kar je vodilo v upore in osamosvajanja, dokler ni turškega teritorija preprosto zmanjkalo. V te burne procese osvobojajočih se nacionalnih sil so se dinamično vključevale zunanje sile, od začetka le habsburški imperij in carska Rusija, pozneje tudi Francija, britanski imperij, Italija in Nemčija. Politični zemljevid Balkana je bil rezultanta vseh omenjenih sil, ki so nanj delovale. Še najmanj vpliva je imela otomanska država, saj se je morala uklanjati malim in večjim silam. Take okoliščine so ustvarjale periferni prostor na širokem območju. Balkan je zamujal s procesi družbene modernizacije in povečeval svojo gospodarsko in tehnološko odvisnost od velikih sil.

\subsection{Razvoj moderne srbske države}

Novo politično jedro srbstva je postalo ozemlje Šumadije na severu. Beograjski pašaluk je zaradi mednarodnih razmer in pritiskov na Turčijo pridobil nekatere ugodnosti predvsem na cerkvenem in kulturnem področju (Laffan, 1989, str. 25-28). Ponovni turški pritiski so leta 1804 sprožili prvo srbsko vstajo pod vodstvom Karađorđa. Osvobojeno ozemlje je imelo le kratek vek, do 1813, ko so ga turške sile ponovno osvojile, vendar ne za dolgo. Leta 1815 je sledil drugi srbski upor pod vodstvom Mihajla Obrenovića, katerega uspeh je zagotovil polavtonomen položaj Srbov znotraj turškega imperija. Obrenovićeva gospodarska in diplomatska spretnost je kmalu zagotovila praktično polno avtonomijo Srbije in jo leta 1830 tudi formalno dosegla. S tem so bili dani pogoji za oblikovanje državnih oziroma nacionalnih institucij. Na področju notranje politike se je krepil državni centralizem, navzven pa so sledili načrtom teritorialnega širjenja Srbije predvsem proti jugu in zahodu v Bosno, ki je bila tedaj še pod turško upravo (Klemenčič, Žagar, 2004, str. 44).

Leta 1844 je I. Garašanin izdelal Načertanije, dejansko geopolitični načrt razvoja srbske države. Garašanin ni bil edini in verjetno tudi ne glavni avtor tega načrta. Besedilo se pripisuje predvsem Franzu Zachu, voditelj poljske emigracije Adam Czartoryszki naj bi mu svetoval, Garašanin pa je na teh podlagah dodal vrsto lastnih idej o političnem razvoju Srbije. Dokument dokazuje smelost in zrelost diplomatskega in političnega razmišljanja še v prvi polovici 19. st., torej v času silovitega vzpona nacionalne ideje v Evropi. $\mathrm{Na}$ čertanije izpostavlja dve ključni izhodišči: a) etnično (enoten etnični razvoj Srbov, kar bi omogočili z združevanjem južnih Slovanov na ozemljih pod otomansko in habsburško oblastjo) in b) teritorialno (pridobitev izhoda na morje) (Garašanin, 1958, str. 428-429). Po Garašaninu je tak načrt definiran kot zgodovinsko utemeljena pravica Srbov do jadranske obale ter vzpostavljanje enotne države nad ozemlji s srbskim prebivalstvom v Bosni in Hercegovini, Vojvodini, na jugu proti Kosovu in Makedoniji ter tudi v Črni gori (Vrkatić, 2004, str. 116). 
Poznejše interpretacije tega dokumenta so zlasti v jugoslovanski historiografiji opredeljevale Garašaninov načrt kot eno izmed 'zrelih' jugoslovanskih idej in ga postavljale ob bok 'ilirski' ideji, ki se je razvila med južnoslovanskimi narodi znotraj habsburške Avstrije (Jugoslavija, 1962, str. 107-111). Pisci so tej interpretaciji dodali ideološko-razredno noto, po kateri je bil beg izpod dveh hegemonij (turške in habsburške) rešitev za manj številčne narode. Toda Načertanije je bil predvsem srbski nacionalni načrt, ki je skušal dosego teritorialnega cilja (južnoslovanske dežele z dostopom do odprtega morja) uresničevati prek etnične homogenizacije. To je po svoji naravi pravzaprav velikosrbska ideja.

Taka koncepcija je bila za Evropo sredi 19. st. tipična, saj je predstavljala ideologijo teritorialnega povezovanja po etničnem ključu. Narodna pripadnost je postala kapital. Nekoliko pozneje sta najprej Italija (1866) in nato še Nemčija (1871) presegli dotedanjo razdeljenost na množico teritorijev (kneževin, držav, mestnih držav ipd.) in se teritorialno zaokrožili na ozemlju, ki naj bi po »kulturi, jeziku in zgodovinski izkušnji...«pripadalo izbrani skupnosti. Kriterij enotnosti je bil jezik, širše vzeto tudi pojem kulture, ki pa so ga različno razlagali (Seton-Watson, 1980, str. 103-123). Ti principi so bili tedaj malodane univerzalni pristop evropskih nacionalizmov na poti združevanja političnih enot ali pa vzpostavljanja teh enot z osamosvajanjem. Vzniknila je poljska, romunska, srbska, bolgarska in grška 'velika' ideja s predpostavko, da je potrebno zaradi uresničitve skupnih interesov preseči včerajšnje razlike. Hegemonizem manjših narodov naj bi torej le-te branil pred teritorialnim pohlepom velikih sil. Srbski politični program je bil torej v luči primerjave rastočih evropskih nacionalizmov 19. st. tipičen evropski pojav, s hegemonistično naravo vred (Hobsbawm, 2012, str. 58-85).

V tistem času (sreda 19. st.) je Srbija razpolagala z naslednjimi možnostmi teritorialnega širjenja: širjenje kneževine Srbije proti jugu, povezanost s Črno goro, na katero jo je vezal jezik in tudi tradicija političnega sodelovanja, in Srbsko Vojvodino, organizirano kot vojna krajina (frontier). Poleg tega je resno računala na dve strateški smeri: proti zahodu (Bosna; t. i. prećanska Srbija) in proti jugu, s Kosovim kot zgodovinsko-kulturnim jedrom ter severno Albanijo (pretežno zaradi strateških razlogov - dostopa do morja). Te smeri so kasneje doživele poskuse uresničevanja, vendar z različnim uspehom.

Ideja o nuji politične povezave med Črno goro in Srbijo ima precej stare korenine, ki segajo še v dobo začetka razvoja srednjeveških držav, v tem primeru Duklje in Zete ter Raške (Ćorović, 2001). Drugi temelj je jezik, ki so ga v panslavistični maniri skušali poenotovati tam, kjer to dejansko ni bilo mogoče (npr. ilirska ideja o združevanju Slovencev, Hrvatov, Srbov ... na podlagi enotnega 'ilirskega' jezika). Ilirizem je bil, politično gledano, ideološki konstrukt v službi unitarizma. Srbski in črnogorski jezik pa sta se veliko manj razlikovala in ta podobnost, razlagana kot istost, je bila eden od argumentov srbsko-črnogorske unifikacije (Pleterski, 1986, str. 34). Podlovćenska Črna gora je kljub ozemeljski in prebivalstveni majhnosti prva dosegla neodvisnost od turških oblasti, zaradi česar je bila v nekaterih ozirih prepoznana kot 'srbska Šparta' (Pleterski, 1986, str. 33-39). Kot argumentacijo srbskega značaja Črne gore mnogi navajajo Njegoševo razumevanje srbstva. Toda le-to je po Popoviću (1999) racionalno, naslonjeno na skupne interese in sosedstvo, medtem ko v kulturi izraža Njegoš črnogorsko individualnost, čeprav vpeto $\mathrm{v}$ takrat razširjeno in popularno pansrbsko (realno pa tedaj južnoslovansko) idejo 
oziroma ima tudi panslovanski značaj. Njegoševa naziranja o tem vprašanju je torej treba jemati časovno in prostorsko omejeno in ne absolutno. In končno si je tudi jezik tedaj šele zares utiral svojo pot (Popović, 1999, str. 89). Črna gora je od začetkov samostojnosti proti koncu 18. st. do podgoriške skupščine 1918 dokazovala avtonomnost in državotvornost, naslonjeno bolj na teritorij in državniško tradicijo kot pa na jezikovno-kulturno dimenzijo etnične pripadnosti; prav to pa jim je tedaj in pozneje potrjevalo nacionalno samobitnost (Zupančič, 2011).

Srbska Vojvodina je imela največ gospodarskih in najmanj političnih možnosti, saj je bila po definiciji strateški rob rastočega habsburškega imperija, po socialni strukturi odvisna od državnih služb (v carini, vojski in državni administraciji) kljub odličnim pogojem za kmetijstvo, in obenem izrazito multietnična. Srbi so (poleg Madžarov v Bački in Nemcev v Banatu) predstavljali številčno in močno, a nikakor ne prevladujočo etnično skupnost (Kocsis, Kocsis-Hodosi, 2001, str. 137-156). Vrh tega je bila poselitev precej sporadična, razen v Sremu, kjer so imeli Srbi regionalno prevlado in vrsto samostanov kot pomembnih verskih in kulturnih središč. Delež Srbov je zaradi nenehnega doseljevanja iz Srbije in Bosne stalno naraščal, krepil pa se je tudi njihov gospodarski položaj (Klemenčič, Zupančič, 2004).

Bosna in Hercegovina je bila najzahodnejša turška evropska provinca. Prebivalstvo je bilo jezikovno dokaj enotno, versko in kulturno pa nikakor ne. Glavna socialna, politična in kulturna ločnica je bila verska pripadnost, ki je dajala islamskemu prebivalstvu več socialnih možnosti in pravic. O izvoru in poteku islamizacije je več domnev. Nekoč uveljavljeno prepričanje, da je do islamizacije prišlo masovno posebej med patareni bogomili ${ }^{7}$, novejše raziskave zavračajo (Judah, 2008, str. 79). Bolj verjetno je bila islamizacija sorazmerno postopna, večgeneracijska in vsaj določeno obdobje nepopolna. Robna lega in vojaška organizacija ozemlja Bosne sta te procese spodbujali, še posebej gospodarsko-socialno (Filipović, 2008, str. 97-134). Ozemlje je bilo pravzaprav v celoti vojna krajina, teritorialno pa za obrambne potrebe razdeljeno na sistem kapetanij (Bojić, 2001, str. 67-68). Gospodarstvo je močno nazadovalo, saj je bila dežela odrezana od turških vitalnih središč, neposredno pa obkrožena z večinoma redko naseljenimi, perifernimi območji. Večina njenih meja je potekala po naravnih ovirah, po rekah (Uni, Savi in Drini) ter gorskih pregrajah. Zaradi kaotičnega in na splošno slabega gospodarskega stanja je pogosto prihajalo do lokalnih uporov, kar je še povečevalo upravno anarhijo (Bojić, 2001, str. 81-84).

Bosna je bila prepričljiva srbska strateška izbira že zaradi izoliranega položaja ter prevlade srbskega ${ }^{8}$ jezika. Ozemlje je bilo zaokroženo in ustrezno utrjeno. Na zunanjem robu Bosne v t. i. vojni krajini na današnjem Hrvaškem je srbsko prebivalstvo prevladovalo, zato je bila videti argumentacija o srbskem kulturnem značaju Bosne tedaj prepričljiva (Ćorović, 2001), predvsem pa v luči povprečja evropskih nacionalizmov, naslonjenih na

7 Bogomilstvo (patarenstvo) je bilo oblika verskih razkolov znotraj katoliške Evrope v srednjem veku. Ločine so smatrali za krivoverske in jih v Srednji in Zahodni Evropi množično preganjali in uničevali, na Balkanu pa se je zaradi bližajoče se turške nevarnosti gibanje ohranilo.

8 Takšno je bilo splošno prepričanje, saj je bil jezik ne glede na regionalne ali kulturne vidike pripadnosti, komunikacijsko enoten (Judah, 2009, str. 79). 
jezikovne kriterije, povsem upravičena (Vrkatić, 2004). Toda srbske strateške namere je prehitela Avstro-Ogrska, ko je po vojnah s Turčijo na berlinskem kongresu leta 1878 dosegla pravico do okupacije Bosne in Hercegovine, Sandžak, gorato ozemlje s pretežno islamskim prebivalstvom med Srbijo in Črno goro, pa je dobilo avstrijske vojaške posadke. Srbiji je bila začasno preprečena možnost širjenja na ozemlje Bosne ter v smeri proti morju (mimo ali prek Črne gore; Laffan, 1989, str. 39-60). Prihod Avstro-Ogrske v Bosno je spodbudil modernizacijske procese. Da bi preprečili močne srbske vplive, so skušali spodbujati ohranjanje posebnosti muslimanskega prebivalstva, kot je npr. uvedba Bošnjakov v elitnih enotah avstro-ogrske armade (Schachinger, 1989, str. 23-30). Srbsko nezadovoljstvo se je še stopnjevalo z avstro-ogrsko aneksijo Bosne in Hercegovine leta 1908.

Srbiji je preostal le ozemeljski prodor proti jugu. Na vzhodu se je okrepila Bolgarija in pričela tekmovati za iste ozemeljske cilje. Makedonija je postala presečišče interesov obeh držav ter dodatno še Grčije, ki je videla priložnosti svojega ozemeljskega širjenja predvsem na severu. Tekmovanje med temi tremi silami se je pričelo že pod turško upravo in se stopnjevalo obratnosorazmerno z močjo turške administracije (Zupančič, 2008). Na ozemlju sedanje Makedonije so grške šole imele še največ uspeha, zahvaljujoč obilni podpori iz grške diaspore (Boeckh, 2009, str. 77-78).

Zunanji pritiski Rusije in Avstro-Ogrske, pa tudi Italije, Francije in Velike Britanije na turška ozemlja so 'bolnika ob Bosporju' izdatno oslabili. Združitev štirih balkanskih držav (Srbije, Bolgarije, Grčije in Črne gore) v skupnem interesu pregona turških vojaških in civilnih sil z Balkana je leta 1912 uspela. Razen ozemlja v neposrednem zaledju Carigrada (Istanbula) je Turčija na Balkanu prenehala obstajati. Procese so spremljali pregoni in beg turškega prebivalstva ne le zaradi neposredne ogroženosti, temveč tudi zaradi gospodarskih razmer. Po ocenah se je v letu ali dveh umaknilo v Turčijo več kot 400.000 oseb turškega etničnega ali drugega muslimanskega prebivalstva (Gerolymatos, 2002, str. 197-207). Nesoglasja zaradi delitvene bilance in s tem uresničevanje nacionalnih ambicij glede teritorialnega širjenja je pripeljalo do dveh balkanskih vojn, $v$ katerih je morala Bolgarija odstopiti ozemlja svojim tekmicam, po določitvah miru v Bukarešti (1913) pa tudi Romuniji (del Dobrudže) in Turčiji (Vzhodna Trakija; Laffan, 1989, str. 152-157). Srbija je pridobila ozemlja predvsem v smeri proti jugu, do današnjega ozemlja Makedonije in se povečala vsaj za polovico. Nista pa ji uspela dva ključna cilja: osvojitev ozemelj s srbsko govorečim prebivalstvom (ali zelo podobnih) in neposreden dostop do morske obale. Na mirovni konferenci v Bukarešti (1913) so imele močan vpliv velike evropske sile, ki so, posebej pod nemškim pritiskom, prispevale k oblikovanju albanske nacionalne države (Ćorović, 2001). S tem je Srbija ostala celinsko zaprta država.

Druga ključna okoliščina Srbije po balkanskih vojnah je bila izrazita etnična pomešanost. Kosovo, zgodovinsko in z nacionalnimi miti prežeto ozemlje, je bilo tedaj že precej albanizirano, povsem agrarno in periferno. Peć, simbolni kraj z izjemno srbsko sakralno dediščino, je ostal v Črni gori. Vardarska Makedonija ni bila etnično srbsko, pač pa makedonsko, regionalno pa tudi precej albansko in turško ozemlje. Podobno izkušnjo so pridobile vse balkanske države, saj je bilo teritorialno širjenje povezano z osvojitvijo etnično zelo raznolikih ozemelj. Poleg tega so na oblikovanje političnih meja bistveno vplivala še razmerja med tedanjimi evropskimi silami. 
Na politično-teritorialne spremembe ni bilo treba dolgo čakati. Komaj leto pozneje je incident v Sarajevu (junija 1914) zanetil prvi globalni spopad. Začel se je na Balkanu, na in zaradi presečišča interesov širjenja srbske države ter avstrijske obrambe pred njim. V tem spopadu so se znova soočile mlade balkanske države, pripadajoče dvema ideološko-vojaškima paktoma: centralnim silam in silam antante. Začetnim uspehom je sledila nemško-avstrijska invazija na eni ter bolgarska agresija na drugi strani. Srbija je bila v tej vojni gospodarsko in vojaško osiromašena, a je iz nje izšla kot zmagovalka in zato, ob izdatnem vplivu močnih antantnih zaveznic, merodajen regionalni politični dejavnik. Pridobila je nekaj manjših ozemelj na vzhodu na račun poražene Bolgarije (ob Timoku, Surdulici in v Strumiški kotlini). Toda odločilni geopolitični preobrat se je zgodil zaradi realizacije jugoslovanske ideje.

\subsection{Jugoslavija, njena kriza in razkroj}

Združitev Srbije in Črne gore leta 1918 na t. i. podgoriški skupščini je še vedno predmet razprave o tem, v kolikšni meri je bil to sporazum (Ćorović, 2001) in v kolikšni meri odraz srbske hegemonije (Pleterski, 1986, str. 155-157). Pomemben del črnogorske javnosti je tej odločitvi močno nasprotoval, posebej na območjih 'stare' Črne gore (Pavlović, 1999). Toda združitev se je zgodila in to je bil prvi del združevalnega procesa na širokem ozemlju od Julijskih Alp do Strumice, na katerem je kmalu za skoraj stoletje nastala Jugoslavija. Drugi združitveni proces je potekal na ozemlju pod nekdanjo habsburško državo. Pri tem so hrvaške in slovenske politične sile vodili pragmatični vidiki obrambe pred premočnim germanskim in ogrskim, pa tudi italijanskim sosedstvom. Srbsko prebivalstvo Bosne in Hercegovine, Vojvodine in Hrvaške pa je, nasprotno, doživljalo akt združitve kot primarno etnični cilj srbskega nacionalizma, torej združitev vseh Srbov v eni državi. Bošnjaška, črnogorska in makedonska narodna identiteta uradno niso obstajale. Tri številčne manjšine, madžarska, nemška in albanska s po približno pol milijona pripadnikov, niso imele političnih manjšinskih pravic in so zato nove razmere doživljale kot zgodovinsko krivico in kot okupacijo.

V pogojih, ko je srbski živelj v novi državi predstavljal le relativno večino (okrog $39 \%$ ) in je njihov najbližji konkurent - Hrvatje - predstavljal okrog $23 \%$ prebivalstva, je bila izbira državnega unitarizma in centralizma videti sicer pragmatična odločitev (Judah, 2009, str. 16-108), dolgoročno pa je verjetno tlakovala pot nezadovoljstvu in separatističnim manjšinskim nacionalizmom (Boeckh, 2009, str. 102-104), ki so se dvajset let pozneje tudi uresničili z razpadom države oziroma njeno razdelitvijo med notranje sile in nekatere zunanje deležnike (Klemenčič, Žagar, 2004). Centralizem in unitarizem nekateri razlagajo kot nujo spričo dejstva, da so se združila ozemlja z zelo različno upravno-administrativno tradicijo (turško na jugu, srbsko v osredju, habsburško oziroma ogrsko v severozahodnem delu) ter da so imele tudi dežele znotraj avstro-ogrskega državnega okvira različne izkušnje in pravice (Petranović, 1980, str. 35-45). Po drugi strani so bile opisane razmere tipične za celoten pas t. i. 'vmesne Evrope' od Baltika do Jadrana in Egejskega morja. Poljska, Češkoslovaška, Romunija in Jugoslavija so bile tvorbe, ki so nastale na ruševinah nedavnih velikih imperijev (ruskega, nemškega, habsburškega in otomanskega) 
in so imele v kritičnem obdobju izrazito večetnično sestavo, številčne manjšine in različno upravno-administrativno dediščino. Razen Češke so bile vse v očitnem zaostanku glede urbaniziranosti in industrializiranosti ter potemtakem gospodarsko in tehnološko odvisne od konkurentov, ki so jih do tedaj ogrožali (Tunjić, 2004, str. 188-195).

Realizacija jugoslovanske ideje je ustrezala idejam srbskega nacionalizma, saj je dosegel ključne geopolitične cilje: združitev velike večine Srbov v eni državi, dostop do morja in za nameček še sorazmerno moč in vpliv. Jugoslavija je postala 'policist na Balkanu', kljub gospodarski šibkosti in notranjepolitičnim težavam, ki jih ni bilo mogoče spregledati (Laffan, 1989, str. 47-60). Nadaljnji proces unitarizacije Jugoslavije je naletel na precejšen odpor, kar je slabilo nominalno sicer močno državo (Klemenčič, Žagar, 2004, str. 50-62). Kljub temu je srbstvo kot etnična kategorija doživelo izjemen vzpon, vendar regionalno zelo neenakomerno. Periferne srbske pokrajine, kot npr. na območju t. i. vojne krajine, pa v Bosni in Hercegovini, vzhodni in južni Srbiji, so imele od krepitve osrednjih predelov le malo koristi.

Enotnost države ni prestala zunanjih pritiskov. Ob nemški, italijanski, madžarski in bolgarski agresiji leta 1941 je država razpadla. Robne predele so si razdelile agresivne sosede, osrednji del nekdanjega jugoslovanskega državnega ozemlja pa so zavzele tri marionetne države (Neodvisna država Hrvaška, Črna gora in Srbija), ki so bile pod nadzorom nemških in italijanskih vojaških sil in so s tem sledile podobni usodi celotne 'vmesne Evrope' na začetku druge svetovne vojne. Novi teritoriji so bili rezultat politično-teritorialnega drobljenja, ki je tokrat potekalo predvsem pod taktirko nemške geopolitike. Ta je, iščoč balkansko polovico svojega 'Lebensrauma', ${ }^{\text {, }}$ ustvarjal labilno strateško cono v celotnem pasu med Baltikom, črnomorskim, egejskim in jadranskim bazenom. Nekatera ozemlja na robu Tretjega rajha so postala nove politične enote ali le njihov del. $\mathrm{S}$ številčno madžarsko skupnostjo naseljena Bačka je pripadla Madžarski, Banat z nemškim prebivalstvom je postal ozemlje pod neposredno nemško vojaško upravo, Kosovo si je pripojila balistična Albanija, Srem in obširna ozemlja nekdanjih vojnih krajin na Hrvaškem so v okviru NDH doživljala izdatno periferizacijo, Črna gora je bila italijanska marionetna politična enota, južno Srbijo (Makedonijo) je dobila Bolgarija. Srbija je za krajši čas postala regionalno povsem nepomemben igralec na evropskem političnem zemljevidu (Boeckh, 2009, str. 218-227).

Restavracija jugoslovanske države po uspešnem partizanskem bojevanju je bila zasnovana na novih, federalističnih načelih. Državo so oblikovali glede na etnične značilnosti prebivalstva, kar naj bi bilo glavno vodilo pri oblikovanju notranjih političnih meja (Petranović, 1980, str. 105-130), a je bilo v resnici daleč od tega. Pri notranjih razmejitvah so v precejšnji meri izhajali iz starih političnih meja (npr. meje Bosne in Hercegovine, deloma Hrvaške, meje Črne gore), deloma so bile rezultat različnih kompromisov (meja Hrvaške v Sremu, meja med Slovenijo in Hrvaško v Istri, pripojitev Boke kotorske Črni

9 Lebensraum (nem. življenjski prostor) je oznaka za teritorij oziroma prostor, ki ga po naziranju nemške klasične geopolitične šole potrebuje neka država za normalen razvoj. V nemškem primeru je bil 'Lebensraum' opredeljen kot ozemlje v vzhodnoevropskih ravninah, bogatih s plodnimi zemljišči, rudami in drugimi viri. Ta prostor so naseljevali slovanski narodi, Nemčija pa naj bi bila upravičena tudi do uporabe vojaške sile za pridobitev tega prostora. 
gori, severna meja Makedonije), deloma pa tehtanja etničnih razmerij (Kosovo). Prav kosovsko vprašanje je zelo zaposlovalo notranjepolitično sceno, saj so bili Srbi nezadovoljni tako z omejitvijo kakor z imenovanjem in ureditvijo (Judah, 2009, str. 136-141). Notranje delitve so torej bolj kot načela vodili pragmatizmi in kalkulacije. Pri tem srbski etnični element ni bil več ključno vezivo večnacionalne Jugoslavije, vsaj v začetku ne. Po nekaterih ocenah naj bi srbski nacionalizem celo nekoliko zavirali. Toda delitev je izhajala iz podmene o trajnosti jugoslovanske federacije in morda tudi zaupanja, da se lahko srbski vpliv samo povečuje (Pleterski, 1986). S tem razmejevanjem ter poznejšo ustavo leta 1974, ki je dala zveznim republikam večje pristojnosti, so nastale neposredne podlage za sedanje politične meje držav na ozemlju nekdanje Jugoslavije.

Jugoslavija se je po ločitvi od bloka socialističnih držav (1948), ureditvi mejnih vprašanj s sosedami in politično-pravnem zaključku druge svetovne vojne (med 1954 in 1957) umestila kot dejanska, a specifična geopolitična enota Jugovzhodne Evrope. Izrazit maritimni položaj, politika neuvrščenosti in ambiciozni načrti gospodarske prenove na temeljih industrijsko-agrarne paradigme so naglo spremenili socialno strukturo prebivalstva in podobo države. Srbski skupnosti je jugoslovanski okvir ustrezal ne le zaradi realnega uresničenja starih nacionalnih ciljev (enotna močna država vseh Srbov ob uveljavljanju srbskega (tedaj srbohrvaškega) jezika), temveč tudi zaradi osrednjega položaja v državi. Predvsem jedro države z Beogradom je imelo vrsto razvojnih prednosti. Vsaj do nekaterih območij, npr. Kosova, je veljala pokroviteljska politika (Petritsch, Kaser, Pichler, 1999, str. 135-144), nekateri pa to primerjajo s polkolonialnim odnosom (Hofbauer, 2008, str. $71-75)^{10}$. Od poznih sedemdesetih let dalje se je krepil jugoslovanski centralizem, kar pa so v ostalih republikah razumeli kot omejevanje lastnega gospodarskega položaja ter na jezikovno-kulturnem področju kot uveljavljanje predvsem srbskih idej, pravzaprav kot velikosrbski nacionalizem (Klemenčič, Žagar, 2004, str. 69-77). Toda etnocentralizem je veljal tudi znotraj srbske etnične kontinuitete, saj je uveljavljal pokroviteljstvo 'jedra' nad periferijami, s čimer zanesljivo ni prispeval k moči perifernih območij. Regionalna politika je pospeševala periferizacijo nekaterih območij, npr. vzhodne in južne Srbije. Takšna percepcija je vodila v poznejše zaostrovanje odnosov in slednjič do serije vojn (Pirjevec, 2003, str. 16-19).

Jugoslovanska kriza je bila prvenstveno odraz notranjih in ne toliko zunanjih silnic, čeprav je bilo precej namigovanj, da so imele tuje sile precejšen vpliv na razpad Jugoslavije (Judah, 2009, str. 169-185). Neuspešno socialistično gospodarstvo, rastoči stroški državne administracije in predimenzionirane armade ter tudi njena trajna 'revolucionarna' vloga so stopnjevale stiske, ki jih je skušala jugoslovanska politična elita pod srbsko taktirko S. Miloševića reševati z večjo vlogo državnega intervencionizma. Ta je bil mogoč predvsem s povečevanjem centralizacije, kar pa je bilo povsem v nasprotju s pričakovanji in potrebami drugih zveznih enot in - kar se rado pozablja - tudi srbskih periferij (Janjić, 2002). Tako se je postopoma in niti ne načrtno oblikovala de facto asimetrična federacija z diametralno različnimi pričakovanji glede političnega razvoja. Država se je razkrajala politično in

10 Hofbauerjeva pronicljiva študija političnega, kulturnega in gospodarskega razvoja je ostra kritika ne le srbskega odnosa do te nekdanje jugoslovanske pokrajine, temveč v enaki meri tudi do eksperimentiranja velikih sil po koncu kosovskega konflikta leta 1999. Kosovo je nesporno pod skrbništvom - potrebnim in nepotrebnim. 
gospodarsko, propad socializma kot družbene ureditve v Evropi pa je te procese še pospešil. Federacija je klonila na celi črti in v zadnji dekadi 20. st. razpadla na niz držav naslednic.

Razkroj Jugoslavije je bil za Srbe skrajno neugoden. V obdobju dveh Jugoslavij, tako monarhično-centralistične kakor socialistično-federativne, je srbstvo predstavljalo jedro države in je bilo združeno v močni državi z opaznim mednarodnim vplivom. Razpad je pomenil tudi razkroj enotnega srbskega etničnega telesa, ki bi se v vsaki različici razkroja jugoslovanske federacije končal z opaznim zmanjšanjem srbske geopolitične veljave, še posebej kar zadeva njeno konkurenčnost v regionalnem kontekstu osrčja Balkana. Toda preden analiziramo današnji geopolitični položaj srbstva, je primerno opozoriti na procese teritorialno-političnega in etničnega razvoja, saj predstavljajo tipično zaporedje poslabševanja razmer (politične periferizacije) kot posledice teritorialnega drobljenja.

Prvi primer teritorialnega drobljenja se je pojavil na Hrvaškem, kjer je nekoč razmeroma številčna in vplivna srbska skupnost (več kot 500.000 pripadnikov), ki pa živi večidel na perifernih območjih zgodovinskih 'vojnih krajin', ob izdatni pomoči jugoslovanske vojske organizirala paradržavne teritorialne organizacije - krajine. Te so zadržale politično oblast $\mathrm{v}$ srbskih rokah, a so se z nadaljnjim potekom vojn gospodarsko izčrpavale, kljub materialni pomoči srbskega jedra. Ta uporniška ozemlja so sicer godila srbskemu nacionalizmu, a so izčrpavala tudi 'matico' in naposled prešle v izrazito 'vojno ekonomijo’ (Pirjevec, 2003, str. 70-113). Okrepljen in naposled dovolj močan hrvaški pritisk jih je v zaporedju vojaških akcij leta 1995 porazil, veliko prebivalstva se je odselilo v Bosno in Hercegovino ter Srbijo. Srbski etnični teritorij se sicer ni skrčil, je pa demografsko nedvomno oslabel. Ta območja so še sedaj kontaminirana z eksplozivnimi sredstvi, kar ovira gospodarski razvoj in tudi morebitno vračanje srbskega življa.

V Bosni in Hercegovini je državljanska vojna potekala drugače. Zaradi izrazite lokalne etnične pomešanosti prebivalstva tvorbe, kot so bile 'krajine' na Hrvaškem, tu niso nastale. Začasno so se oblikovala zgostitvena jedra beguncev ene ali druge etnične skupnosti, saj so imele kot etnični otoki - enklave večje možnosti preživetja. Tekom vojne so se te enklave dinamično spreminjale in bistveno vplivale na številčnost in regionalno razporeditev prebivalstva glede na etnično pripadnost. Bosna in Hercegovina je v tem dramatičnem vojnem procesu izgubila več kot 200.000 prebivalcev, polovica državljanov pa je spremenila kraj bivanja. Obenem je prišlo tudi do izrazite koncentracije v mestnih območjih - torej do pojava t. i. krizne urbanizacije (Burg, Shoup, 1999).

Mednarodni dejavniki so skušali vojno ustavljati, vendar so mirovne pobude propadale druga za drugo. Gordijski vozel diplomatskih mirovnih neuspehov je presekal šele daytonski sporazum - pravzaprav diktat - novembra 1995. Bosna in Hercegovina je navzven ohranila teritorialno integriteto, notranje pa so jo oblikovali v zapleten sistem dvostopenjske federativne ureditve. Uvedba dveh entitet, Republike Srbske in bošnjaško-hrvaške federacije, ki se nadalje členi v hrvaške, bošnjaške in mešane kantone, je sicer prinesla mir (vzdržujejo ga močne mednarodne mirovne sile), za upravljanje pa je zelo zapletena in draga rešitev. Uničena gospodarska, družbena in prometna infrastruktura je radikalno znižala možnosti gospodarskega vzpona še leta pozneje, deloma tudi zaradi množične prisotnosti min in neeksplodiranih bojnih sredstev (Pirjevec, 2003). Poleg tega so vse etnične skupine doživele tudi temeljito demografsko regresijo, saj je nuja po 
ekonomskem preživetju pognala v izseljenstvo, začasno ali za stalno, tisoče ljudi. Tudi beguncem je oteženo vračanje zaradi nejasnih perspektiv daytonske Bosne in Hercegovine. Težave povzročajo tudi nejasne in neurejene pravnoposestne razmere preseljenega prebivalstva (Toal, Dahlman, 2011).

Srbija se je spopadom na lastnih tleh izognila, izvzemivši Kosovo. Vendar je veliko prebivalcev neposredno sodelovalo v spopadih na Hrvaškem in v Bosni in Hercegovini in ne nazadnje na Kosovu. V multietnični Vojvodini je občasno prihajalo do konfrontacij med srbsko večino in madžarsko manjšino, do odprtih spopadov pa ne. Vendar je bilo veliko posrednih učinkov, zlasti demografskih in gospodarskih. Odseljevali so se vsi, še posebej pripadniki manjšin (Klemenčič, Zupančič, 2004). Problem demografskega nazadovanja je sicer starejši, saj je bila osrednja in še posebej vzhodna Srbija demografsko šibka že v osemdesetih letih 20. st., pozneje pa se je ta proces samo še stopnjeval (Radovanović, 1995). Srbija je tonila v mednarodno osamo, vojna bremena so izčrpala rezerve in uveljavile so se prakse sive ekonomije v napol vojnih razmerah.

Nekoliko drugačen zaplet je nastal na Kosovu. Manj kot $11.000 \mathrm{~km}^{2}$ veliko, a gosto naseljeno ozemlje je bilo zaradi izrazito multietnične sestave prebivalstva že v preteklosti nevralgično območje jugoslovanske federacije (Mišović, 1987). Problemi so se pozneje le stopnjevali vse do vojaških spopadov med letoma 1997 in 1999, ko je zaradi policijsko-vojaške akcije zveze NATO ZR Jugoslavija postala tarča mednarodne vojaške intervencije. Pravna in politična posledica srbskega poraza je bila zasedba Kosova s strani mednarodnih sil, nato pa je to februarja 2008 - še vedno pod budnim mednarodnim nadzorom - razglasilo neodvisnost.

Zgodovina albanskega separatizma na Kosovu v okviru nekdanje Jugoslavije je izjemno dolga in korenini v daljnih letnicah 1844 s srbskim Načertanijem (in pozneje Memorandumom V. Čubrilovića leta 1937) ${ }^{11}$ (Petritsch, Kaser, Pichler, 1999, str. 114-127) in nekaj desetletij pozneje še albanskim političnim programom v okviru t. i. prizrenske lige ${ }^{12}$ iz leta 1876 (Rajović, 1985, str. 37-40). Poslej je bil spopad dveh nacionalizmov za isto ozemlje neizbežen. Podelitev določene avtonomije Kosmetu in še posebej preimenovanje v Kosovo ter okrepitev avtonomije leta 1974 so dejansko povečali albanske aspiracije. Odvzem avtonomije leta 1989 je potisnil albanske institucije v ilegalo. Te institucije, od šolstva in zdravstva do kulture, izobraževanja in na koncu tudi varnostnih struktur, so delovale ob izdatni pomoči številčne albanske diaspore (Clark, 2000). Vendar je bila to tudi pot utiranja kriminalnim združbam. Albanska mafija se je lahko prav zaradi kaotičnih razmer in goste naseljenosti dokaj neovirano razvijala in se v fazi vojaških spopadov od 1997 do 1999 celo rekrutirala kot obrambna sila (Lopušina, 2004).

11 Memorandum V. Čubrilovića sodi med pomembne dokumente srbske nacionalne politike iz časov med obema svetovnima vojnama. V njem podrobneje spregovori o potrebnih ukrepih srbske asimilacijske in selitvene politike, s katero bi postopoma uvedli razmerja, ugodnejša za popolno srbsko etnično in politično prevlado.

12 Prizrenska liga je bila narodni program albanske prevlade na večini območja s pretežno albansko poselitvijo, ki je bilo pod turško oblastjo. Na etnično opredeljenem območju naj bi Albanci prevzeli oblast, bodisi povsem samostojno ali pa v okviru turške države (poseben vilajet). Pri tem je bila ključna enotnost albanskega življa ne glede na versko pripadnost. Glavni element albanskega povezovanja je bil jezik. Pozneje so prizrensko ligo pogosto intepretirali kot velikoalbanski načrt - kar je tudi v resnici bil. 
Leta 1999 je ob nadaljevanju in stopnjevanju pritiska na Kosovo sledil vojaški napad zveze NATO na takratno ZR Jugoslavijo. Zasnovan je bil kot omejena vojaška akcija letalskih sil, ki naj bi v nekaj dneh prisilila srbsko (tedaj še jugoslovansko) vojsko in policijo k umiku s Kosova. To je uspelo šele po 79 dneh. Srbija vojaško ni utrpela hujše človeške in materialne škode, gospodarsko in politično pa je bil poraz uničujoč. Bila je prisiljena sprejeti mirovne pogoje, po katerih je Kosovo prešlo povsem pod mednarodni nadzor (Pirjevec, 2003, str. 543) in po desetletju prenehalo obstajati kot del Srbije. Kosovo je najprej postalo varovano območje z obsežnimi mirovnimi silami (KFOR) $)^{13}$ ter mednarodno misijo UNMIK ${ }^{14}$ (Reka, 2003, str. 133-140) in pozneje tudi z evropskim upravno-administrativnim nadzorom (misija EULEX) ${ }^{15}$. Srbsko prebivalstvo se je po odhodu srbske policije in vojske umaknilo v begunstvo ter se zateklo v etnične enklave. Sedaj jih je šest večjih in več kot 50 manjših, izvzemivši območje treh občin na severu Kosova, ki je teritorialno naslonjeno na Srbijo in z njo tudi funkcionalno povezano. Območje Kosovske Mitrovice je dejansko paradržava, teritorij, podoben 'krajinam' na Hrvaškem, le da je njegovo upravljanje predvsem civilno in ne vojaško (Serb community in Kosovo, 2012).

\section{SKLEP: SRBSTVO KOT EVROPSKA GEOPOLITIČNA DILEMA}

Opisani procesi so Srbijo, v jugoslovanskem obdobju močno regionalno silo, najprej oslabili, nato razdelili in slednjič osamili. Periferizacija je bila torej nezadržna posledica politično-teritorialnega drobljenja, do katerega je prihajalo spričo osamosvajanja nekdanjih zveznih republik, predvsem pa zaradi povsem zgrešenega etno-centralističnega pristopa, ki je vodil v serijo lokalnih vojn, Srbijo mednarodno oslabil, demografsko in gospodarsko izčrpal ter celinsko zamejil. Če se vrnemo za stoletje in pol nazaj k Načertaniju, so bili dosežki, ki so nastajali vsaj dobro stoletje, v enem samem desetletju praktično pokopani. Srbiji je namesto vloge regionalne sile ostal položaj povprečnega koščka v osrčju balkanskega političnega zemljevida. V teh procesih se je precej spremenil tudi srbski etnični zemljevid. Na Kosovu in v južni Srbiji se število in delež Srbov zmanjšuje, krepi pa se metropolitansko območje Beograda in tudi Vojvodina, ki sta prejeli večji delež srbskih beguncev z juga in zahoda. Zaradi izseljevanja vztrajno narašča tudi število Srbov v diaspori.

Primerjava demografske in gospodarske moči držav Balkanskega polotoka kaže zanimiva nova razmerja. Srbski prostor je primerljiv z npr. bolgarskim, hrvaškim in albanskim. Od vseh treh je najmočnejši in v središčni legi, toda edini med njimi nima dostopa do morja in je torej geografsko prikrajšan. Regionalne sile v sosedstvu, kot so Madžarska, Romunija in Grčija, predstavljajo demografsko in gospodarsko opazno močnejše 'igralce' na prostoru Balkana, medtem ko imajo 'male' države (Črna gora, Makedonija in tudi Bosna in Hercegovina - zaradi politične razdeljenosti) le obroben pomen.

\footnotetext{
13 Kosovo Forces

14 United Nations Interim Administration Mission in Kosovo

15 European Union Rule of Law Mission in Kosovo
} 
Kakšen je današnji srbski prostor in kakšen je njegov geopolitični pomen?

Strukturo sodobnega srbskega prostora označuje sistem koncentričnih krogov. V njegovem osredju je glavno srbsko jedro - beograjska aglomeracija, ki jo na severu obroblja industrijsko in kmetijsko bogata Vojvodina, na jugu pa gosto naseljena, čeprav gospodarsko šibkejša Šumadija. Sledi pas perifernih območij: na zahodu v Podrinju, na vzhodu med Karpati in Vlaško nižino ter na jugu etnično mešana predela južnega Pomoravja in Sandžaka. Onkraj tega pasu sledi niz manjšinskih območij, ki, odvisno od definicije pripadnosti, odražajo šibke robne dele, srbske 'otoke' in nekdanja ter sedanja paradržavna ozemlja. Še dalje navzven so poselitvena območja srbskih manjšin in diaspore.

Na nekatera vprašanja lahko odgovori le srbska politika: ta zadeva predvsem modus operandi naroda, katerega nacija je v demografsko hirajoči državi z izborno geografsko lego in slabim mednarodnim (političnim) položajem na tem, da se odloči med evropsko prihodnostjo ali pa skuša igrati vlogo eksponenta ruske geopolitike ${ }^{16}$. V prvem primeru mora vzpostaviti dobre odnose s svojim evropskim sosedstvom (kar zaradi odnosov v bližnji preteklosti ni enostavno), v drugem pa igrati vlogo ruskega strateškega sidrišča na Balkanu. Prva vloga sicer prinaša več gospodarskih koristi, še posebej robnim srbskim pokrajinam, druga pa povečuje strateško vrednost srbskega ozemlja, vendar skoraj nujno zmanjšuje pozornost do njegovih robnih predelov. Strateška odločitev bo torej terjala prilagoditev srbske regionalne, demografske in gospodarske politike.

Drugo vprašanje so 'srbska ozemlja' ki so bila v jugoslovanski eri znotraj enotne države, sedaj pa se nahajajo zunaj nje, s tako ali drugačno posebnostjo. Ali je ta konstelacija razmerja med jedrom (ali 'matico') in ostalimi srbskimi območji razmerje vzajemnosti in solidarnosti ali pokroviteljstva, je prav tako bolj ali manj interna odločitev. V danih razmerah je ključno vprašanje, kako funkcionalno povezovati srbstvo v več državah. To je v veliki meri odvisno tudi od zunanjepolitične orientacije, torej proevropske ali proruske. Slednje ni bila tako osamljena ideja, posebno ne v burnih devetdesetih letih prejšnjega stoletja, ko je ZR Jugoslavija zaradi serije lokalnih vojn v sosedstvu računala na Rusijo (Pirjevec, 2003). Evrazijska dimenzija je bila privlačna in večdimenzionalna (Subotić, 2004, str. 6-12).

Prav zaradi teh srbskih opcij je usoda srbskih ozemelj tudi evropska geopolitična dilema. To - vsaj posredno - nakazuje tudi Tunjić (2004, str. 60-62). Očitno je, da si v dvajsetih letih balkanizacije Balkana evropska diplomacija ni izdelala jasne vizije razvoja tega prostora, razen ponavljanja o evropski perspektivi območja in s ponujanjem standardov, po drugi strani pa bode v oči dejstvo, da so bile vse štiri ključne krize na prostoru nekdanje Jugoslavije rešene po zelo neenotnih, pravzaprav sporadičnih poskusih. Srbsko vprašanje na Hrvaškem sta razrešila najprej vojaška akcija in nato erdutski sporazum, rešitev za Bosno in Hercegovino je bil ameriški diplomatski diktat v Daytonu, Kosovo je opredelila resolucija Združenih narodov, po desetletju agonije pa ga je Ahtisaarijev načrt slednjič tudi formalno odtrgal od Srbije, Zahodno Makedonijo pa je zaznamoval ohridski sporazum. Očitno je torej, da jasne vizije ni bilo, pač pa taktika, vsakič nekoliko drugačna in prilagojena drugim mednarodnim razmerjem. Projekti umirjanja so večinoma uspeli,

$16 \mathrm{O}$ tem je mogoče soditi zlasti v okviru t. i. 'naftne' geopolitike, kjer se prikrito, a vendar zelo močno kaže geopolitična tekmovalnost Rusije in EU kot celote. 
načrti revitalizacije pa večinoma ne. Medtem ko je prihodnost držav Zahodnega Balkana s strani EU predvsem 'evropska', ostajajo problemi perifernosti v prvi vrsti predmet regionalnih in manjšinskih politik držav naslednic Jugoslavije. Za Srbe to hkrati pomeni tudi iskanje načinov in oblik povezovanja in sodelovanja med srbsko nacijo (Srbija) ter subnacijo (Republika Srbska) na eni ter številnimi manjšinami v sosedstvu. Tak pristop mora zavrniti etnocentralistične vzorce iz preteklosti in vzpostavljati nova regionalna partnerstva. Pri tem je morda odločilnega pomena moč ‘jedra' srbstva, ki je gospodarsko, demografsko, kulturno osredotočeno v močni beograjski mestni aglomeraciji, enem najpomembnejših vozlišč na Balkanu.

\section{Viri in literatura}

Ancestry - Serbian. 2011. Censushome. Australia census 2011. URL: http://www.abs. gov.au/websitedbs/censushome.nsf/home/factsheetsancserb (Citirano 11. 12. 2013).

Avijucki, V., 2009. Kontinentalne geopolitike. Svet u XXI veku. Kragujevac, Clio, 604 str.

Boeckh, K., 2009. Serbien und Montenegro. Geschichte und Gegenwart. Regensburg, Verlag Friedrich Pustet, 256 str.

Bojić, M., 2001. Historija Bosne i Bošnjaka. Zagreb, BTC Šahinpašić, 635 str.

Bonifazi, C., Mamolo, M., 2004. Past and current trends of Balkan migrations. Espace, populations sociétés, 2004/3, str. 519-531. URL: http://eps.revues.org/356 (Citirano 20. 11. 2013).

Burg, S. L., Shoup, P. S., 1999. The war in Bosnia-Herzegovina. Ethnic conflict and international intervention. New York (Armonk), London (M. E. Sharpe), 499 str.

Cerović, L., 2005. Sârbii din România. Din evul mediu timpuriu până in zilele noastre. Uniunea Sârbilor din România, Timişoara. URL: http://www.banaterra.eu/romana/files/sarbii_din_romania.pdf(Citirano 12.12. 2013).

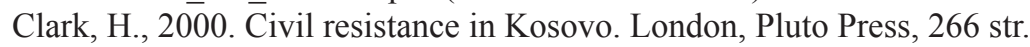

Comprehensive proposal for the Kosovo status settlement. 2007. UN Special Envoy of the Secretary General. UN Security Council. URL: http://www.unosek.org/docref/ Comprehensive_proposal-english.pdf (Citirano 20. 11. 2013).

Ćorović, V., 2001. Istorija srpskog naroda. Beograd, Janus (e-knjiga). URL: http://www. rastko.rs/rastko-bl/istorija/corovic/istorija/index_1.html (Citirano 20. 11. 2013).

Demographic data by municipalities. 2013. Kosovo Agency of Statistics. Tab. 1.7. Population by municipalities, sex and ethnicity, str. 44-46. URL: http://esk.rks-gov.net/ rekos2011/repository/docs/Demographic\%20data\%20by\%20municipalities.pdf (Citirano 21. 11. 2013).

Der neue Fischer Weltalmanach 2014. 2013. Frankfurt am Main, Fischer Verlag, 736 str. Évi Népszámlálás 2011. 2013. Budapest, Országos adatok, 276 str. URL: http://www.ksh. hu/docs/hun/xftp/idoszaki/nepsz2011/nepsz_orsz_2011.pdf (Citirano 21. 11. 2013).

Filipović, N., 2008. Islamizacija u Bosni i Hercegovini. Sarajevo, Armis Print, 556 str. Garašanin, Ilija. 1958. Enciklopedija Jugoslavije. Knj. 3. Dip-Hiđ. Zagreb, Leksikografski zavod FNRJ, str. 428-429. 
Gerolymatos, A., 2002. The Balkan wars. Conquest, revolution and retribution from the Ottoman era to the twentieth century and beyond. New York, Basic books, 335 str.

Hobsbawm, E. J., 2012. Nation and nationalism since 1780. Cambridge, Cambridge University Press, 206 str. URL: http://ebooks.cambridge.org/ebook.jsf?bid=CBO9781139051880 (Citirano 13. 11. 2013).

Hofbauer, H., 2008. Experiment Kosovo. Der Rückkehr des Kolonialismus. Wien, Promedia, 262 str.

Institutul naţional de statistică. 2011. Tab. 8: Populaţia stabilă după etnie - judeţe, municipii, oraşe, comune. URL: http://www.recensamantromania.ro/wp-content/uploads/2013/07/sR_Tab_8.xls (Citirano 12.11.2013).

Janjić, D., 2002. Decentralizacija Kosova. Forum za etničke odnose, Beograd, 149 str.

Judah, T., 2009. The Serbs. History, myth and destruction of Yugoslavia. 3. izd. New Haven in London, Yale University Press, 414 str.

Jugoslavija. VIII. Historija. 1800-1850 in 1850-1914. 1962. Enciklopedija Jugoslavije. Knj. 5. Jugos-Mak. Zagreb, Leksikografski zavod FNRJ, str. 107-111.

Kennedy, P. M., 2002. Aufstieg und Fall der großen Mächte. Ökonomischer Wandel und militärischer Konflikt von 1500 bis 2000. Frankfurt am Main, Fischer Taschenbuch Verlag, 976 str.

Key figures on Europe 2012. 2012. Luxembourg, Publications Office of the European Union, 186 str. URL: http://epp.eurostat.ec.europa.eu/cache/ITY_OFFPUB/KS-EI-12-001/ EN/KS-EI-12-001-EN.PDF (Citirano 13. 11. 2013).

Klemenčič, M., Zupančič, J., 2004. The effects of the dissolution of Yugoslavia on the minority rights of Hungarian and Italian minorities in the post-Yugoslav states. Nationalities papers, 32, 4, str. 853-896.

Klemenčič, M., Žagar, M., 2004. The former Yugoslavia's diverse peoples: a reference sourcebook. Santa Barbara, ABC-Clio, 426 str.

Kocsis, K., Kocsis-Hodosi, E., 2001. Ethnic geography of the Hungarian minorities in the Carpathian basin. Budapest, Simon Publications, 244 str.

Komac, M., Bešter, R., Medved, F., Medvešek, M., Pirc, J., Roter, P., Vrečer, N., 2012. Srbi v Beli krajini. Ljubljana, Inštitut za narodnostna vprašanja, 109 str.

Laffan, R. G. D., 1989. The Serbs. The guardians of the gate. New York, Dorset Press, 299 str.

Lalkov, M., Aleksieva, T., Filčev, B., Hadžitanev, H., Šinkova, J., 2000. Rulers of Bulgaria: khans, tsars and statesmen. Sofija, Kibea, 64 str.

Lopušina, M., 2003. Crnogorski klan. Beograd, NK-Alfa, 448 str.

Lopušina, M., 2004. Albanska mafija: balkanska smrt. Čačak, Legenda, 293 str.

Malcolm, N., 1998. Kosovo: a short history. London, Pan Books, 492 str.

Marković, Z., 2007. Jugoslovanska ljudska armada (1945-1991). Ljubljana, Defensor, $216 \mathrm{str}$.

Mazower, M., 2002. Temna celina. Dvajseto stoletje v Evropi. Ljubljana, Mladinska knjiga, 463 str.

Mišović, M., 1987. Ko je tražio republiku. Kosovo 1945-1985. Beograd, Narodna knjiga, 461 str.

Ostrogorski, G., 1961. Zgodovina Bizanca. Ljubljana, Državna založba Slovenije, 601 str. 
Palić, S., 2011. Četiri miliona Srba našlo uhlebljenje u inostranstvu. Blic online. 2011. URL: http:/www.blic.rs/Vesti/Drustvo/266353/Cetiri-miliona-Srba-naslo-uhlebljenje-u-inostranstvu (Citirano 21. 11. 2013).

Pan, C., Pfeil, B. S., 2000. Die Volksgruppen in Europa. Ein Handbuch. Wien, Braumüller Verlag, 302 str.

Pavlović, S., 1999. The Podgorica assembly in 1918. Notes on the Yugoslav historiography (1919-1980) about the unification of Montenegro and Serbia. Canadian Slavonic papers, 41, 2, str. 157-176.

Petranović, B., 1980. Istorija Jugoslavije 1918-1978. Beograd, Nolit, 648 str.

Petritsch, W., Kaser, K., Pichler, R., 1999. Kosovo, Kosova. Mythen, Daten, Fakten. Klagenfurt / Celovec, Wieser Verlag, 363 str.

Pirjevec, J., 2003. Jugoslovanske vojne 1991-2001. Ljubljana, Cankarjeva založba, 783 str.

Pleterski, J., 1986. Narodi, Jugoslavija, revolucija. Ljubljana, Komunist in Državna založba Slovenije, 426 str.

Popis stanovništva, domačinstava i stanova 2011. u Republici Srbiji. Nacionalna pripadnost: podaci po opštinama i gradovima. Republički zavod za statistiku. URL: http:// pod2.stat.gov.rs/ObjavljenePublikacije/Popis2011/Nacionalna\%20pripadnost-Ethnicity.pdf (Citirano 13. 7. 2013).

Popis stanovništva, kućanstva i stanova 2011. Stanovništvo prema državljanstvu, narodnosti, vjeri i materinskom jeziku. Državni zavod za statistiku Republike Hrvatske. Statistička izvješća, 1469/2012, 132 str. URL: http://www.dzs.hr/Hrv_Eng/publication/2012/SI-1469.pdf (Citirano 14. 9. 2013).

Popović, M., 1999. Crnogorsko pitanje. Ulcinj, Plima, 229 str.

Radovanović, S., 1995. Demographic growth and ethnodemographic changes in the Republic of Serbia. Faculty of geography, University of Belgrade. URL: http://www. rastko.rs/istorija/srbi-balkan/sradovanovic-demography.html (Citirano 3.12. 2012).

Rajović, R., 1985. Autonomija Kosova. Beograd, Ekonomika, 583 str.

Reka, B., 2003. UNMIK as an international governance in post-war Kosova. NATO intervention, UN administration and Kosovar aspirations. Prishtina, Logos-A, 413 str.

Report of the special envoy of the Secretary-General on Kosovo's future status. 2007. United Nations Security Council, 26 March 2007, S 2007/168, 9 str. URL: http:// www.unosek.org/docref/report-english.pdf (Citirano 3.12. 2012).

Riedel, S., 2005. Die Erfindung der Balkanvölker. Identitätspolitik zwischen Konflikt und Integration. Wiesbaden, VS Verlag für Sozialwissenschaften, 386 str.

Sardon, J.- P., 2001. Demographic change in the Balkans since the end of 1980s. Population, 13, 4-5, str. 49-70.

Schachinger, W., 1989. Die Bosniakien kommen. Elitetruppe in der k.u.k. Armee, 18791918. Graz, Leopold Stocker Verlag, 360 str.

Sepp, J., 1983. Weg und Ende der deutschen Volksgruppe in Jugoslawien. Graz, Leopold Stocker Verlag, 346 str.

Serb community in Kosovo. 2012. Helsinki Committee for Human Rights in Serbia. URL: http://www.helsinki.org.rs/doc/Serb\%20Community\%20in\%20Kosovo.pdf (Citirano 12. 9. 2013). 
Serben in Deutschland. 2013. Zentralrat der Serben in Deutschland. URL: http://www. zentralrat-der-serben.de/index.php?Serben_in_Deutschland (Citirano 12. 11. 2013).

Seton-Watson, H., 1980. Nacije i države. Ispitivanje porijekla nacija i politike nacionalizma. Zagreb, Globus, 465 str.

Srbija. 1998. V: Dermastia, A. (ur.). Enciklopedija Slovenije. Knj. 12. Slovenska n-Sz. Ljubljana, Mladinska knjiga, str. 221-243.

Srbi u Albaniji jedna od najugroženih manjina u svetu. 2013. URL: http://www.arhiva. srbija.gov.rs/vesti/1998-09/17/5220.html (Citirano 13. 9. 2013).

Srpska dijaspora. 2013. Internet novine serbske. URL: http:/www.srpskadijaspora.info/ vest.asp?id=2056. (Citirano 13. 9. 2013).

Stanovništvo Crne Gore prema polu, tipu naselja, nacionalnoj, odnosno etničkoj pripadnosti, vjeroispovijesti i maternjem jeziku po opštinama u Crnoj Gori. Popis stanovništva, domaćinstava i stanova u Crnoj Gori 2011. godine. 2011. Saopštenje, 83. Podgorica, Zavod za statistiku. URL: http://www.monstat.org/userfiles/file/popis2011/ saopstenje/saopstenje(1).pdf (Citirano 14. 3. 2012).

Statistical yearbook of the Republic of Macedonia 2005. 2005. Skopje, State Statistical Office of the Republic of Macedonia. Population according to declared ethnic affiliation, by censuses, str. 53. URL: http://www.stat.gov.mk/PrikaziPublikacija en. $\operatorname{aspx}$ ?id=34\&rbr=403 (Citirano 12. 11. 2013).

Statistics Canada. 2011 National household survey: data tables. Ethnic origin. URL: http://www12.statcan.gc.ca/nhs-enm/2011/dp-pd/dt-td/Rp-eng.cfm?LAN$\mathrm{G}=\mathrm{E} \& \mathrm{APATH}=3 \& \mathrm{DETAIL}=0 \& \mathrm{DIM}=0 \& \mathrm{FL}=\mathrm{A} \& \mathrm{FREE}=0 \& \mathrm{GC}=0 \& \mathrm{GID}=0 \&$ $\mathrm{GK}=0 \& \mathrm{GRP}=1 \& \mathrm{PID}=105396 \& \mathrm{PRID}=0 \& \mathrm{PTYPE}=105277 \& \mathrm{~S}=0 \& \mathrm{SHOWAL}-$ $\mathrm{L}=0 \& \mathrm{SUB}=0 \&$ Temporal $=2013 \& \mathrm{THEME}=95 \& \mathrm{VID}=0 \& \mathrm{VNAMEE}=\& \mathrm{VNAMEF}=$ (Citirano 12. 9. 2013).

Statistik Austria, Volkszählung 2001. Bevölkerung 2001 nach Umgangssprache, Staatsangehörigkeit und Geburtsland. URL: http://www.statistik.at/web_de/static/bevoelkerung_2001_nach_umgangssprache_staatsangehoerigkeit_und_geburtsland_022896. pdf (Citirano 20. 3. 2012).

Statistiska centralbyrån 2011. Tabeller över Sveriges befolkning 2006: Tab. 1.1.2. Folkmängd efter födelseland 1900-2006. URL: http://www.scb.se/statistik/_publikationer/BE0101_2006A01_BR_03_BE0107TAB.pdf (Citirano 12. 12. 2013).

Subotić, M., 2004. Put Rusije: evroazijsko stanovište. Beograd, Plato, 326 str.

Switzerland demographics profile 2013. Indexmundi. URL: http://www.indexmundi. com/switzerland/demographics profile.html (Citirano 13. 11. 2013).

Toal, G., Dahlman, C., 2011. Bosnia remade: ethnic cleansing and its reversal. New York, Oxford University Press, 488 str.

Tunjić, F., 2004. Vmesna Evropa. Konfliktnost državnih teritorialnih meja. Koper, Znanstveno-raziskovalno središče Univerze na Primorskem in Zgodovinsko društvo za južno Primorsko, 469 str.

Tunjić, F., 2010. Slovensko-hrvaška državna meja v mejišču Evropske unije. Dela, 33, str. $51-73$. 
United States census 2010. Population. Ancestry (total categories tallied) for people with one or more ancestry categories reported. United States Census Bureau, American FactFinder. URL: http://factfinder2.census.gov/faces/tableservices/jsf/pages/productview.xhtml?pid=DEC_00_SF3_PCT018\&prodType=table (Citirano 21. 9. 2013).

Verska, jezikovna in narodna sestava prebivalstva Slovenije. Popisi 1921-2002. 2003. Statistični urad Republike Slovenije, Posebne publikacije, 2, 169 str. URL: http:// www.stat.si/doc/pub/sestava_preb_slo.pdf(Citirano 12. 12, 2013).

Vrkatić, L., 2004. Pojam i biće srpske nacije. Sremski Karlovci, Novi Sad, Izdavačka knjižarnica Zorana Stojanovića, 902 str.

Zgodovina narodov Jugoslavije. 1953. Knj. 1 (Do začetka XVI. stoletja). Ljubljana, Državna založba Slovenije, 763 str.

Zupančič, J., 2006. Geopolitične razsežnosti makedonskega narodnega vprašanja. Razprave in gradivo, 48/49, str. 124-154.

Zupančič, J., 2008. Albansko vprašanje v luči političnoteritorialne rekonstrukcije Balkana. Razprave in gradivo, 55, str. 6-49.

Zupančič, J., 2009. Političnogeografska analiza Balkana. Dela, 32, str. 85-134.

Zupančič, J., 2010. Geopolitične razsežnosti črnogorskega narodnega vprašanja. Razprave in gradivo, 61, str. 8-40.

Zupančič, J., 2011. The geopolitical dimensions of the Montenegrin national question. Europa Ethnica, 68, 1-2, str. 10-20

\section{GEOPOLITICAL PERSPECTIVES OF SERBIAN QUESTION ONTHE BALKANS}

\section{Summary}

The paper is presenting the geopolitical features of Serbian national question. Thanks to their role in conflicts in former Yugoslavia, the Serbs are considered as one of most disputable nations on Balkan peninsula. However, critically observed, the Serbian nationalism is only one of nationalist ideologies in the region. But, they used to be the 'core' of former Yugoslav multiethnic federation, most numerous and centrally situated; that is why they were considered as the 'guardians of the gate' according to Laffan's writings. This article is a part of much broader study of colorful ethnic mosaic on the Balkans and their geopolitical background. The methodology of this research is following the time-spatially comparative interpretation in three main fields: the balance between inner- and outer forces (functional aspect), geographical structure of researched space (structural aspect), and the forms of political-territorial organization and changes (i.e. morphological aspect).

The contemporary Serbian space is very complicated one. The 'core' is undoubtedly in the agglomeration of Belgrade and its vicinity, with the economically vital Vojvodina to the north and Šumadija to the south. Then follows Serbian periphery in south, south-west and east, characterized by negative demographical trends and poor economic potentials. Then, the Serbs live in parallel sub-state in Bosnia and Hercegovina (Republic of Srpska, 
the Serbian entity of Dayton's Bosnia) with the absolute regional majority. According to the Ahtisaari's plan, the Serbs are treated as constitutional co-nation in multiethnic Kosovo, but the reality is far from this: they are relatively small ethnic community, dispersed in closed ethnic enclaves around this independent country (2008) and strongly marginalized in public life. The only exception is the so called Northern Kosovo with Kosovska Mitrovica and surroundings. Serbian territorial (or historical) minorities are in Croatia, Montenegro, Macedonia, Hungary and Romania. Serbian diaspora is large, particularly in some Central and West European countries, in the USA and Canada. According to estimations, there are more than 10 million Serbs, 6 million in Serbia, 1.5 million in Bosnia, and 0.5 million as minorities in neighboring countries. The diaspora is estimated between 2 to 3.5 or even to 4 million all around the world.

Serbian national mythology knows the 'golden age', i.e. in late medieval period. The 'core' was in contemporary Kosovo. At that time, the region was economically rich and well populated. Because of Ottoman invasion, the country came under Turkish rule for almost 500 years. Serbian population migrated to the west and north. Later in 18th and 19th century, the Serbs gradually liberated the whole country, part by part. They developed the programme of future political-territorial development (Načertanije). The possible directions of this development were to Bosnia, Vojvodina and to the south. After Austrian military occupation of Bosnia and Hercegovina in 1878, the way to the south remained the only option. This was the last occasion when Serbia represented - more or less - an ethnic homogeneous territory.

The next territorial enlargement followed in 1913. According to Bucharest treaty (after the Balkan wars 1912-1913), Serbia acquired 'southern' provinces, i.e. contemporary Kosovo, part of Sanjak and Macedonia and became typical multiethnic state. This was much more evident after WW 1, when the Kingdom of SHS, later the Kingdom of Yugoslavia, was created. The Serbs were considered as the ethnic core of new state, despite they participated with just a good third of population.

Next territorial changes followed during WW 2, after fall of Yugoslav kingdom. Serbia was pushed again to its 'proper' lands. The after-war period was characterized by creation of federal, multiethnic socialist state and recognition of several ethnic communities: Montenegrins, Macedonians and Moslems. Serbia was the largest federal republic, but containing two, partially autonomous political-administrative provinces, Vojvodina and Kosovo (first pronounced as Kosmet), because of their multiethnic character. The creation of autonomuous provinces was the last political-territorial inner division in Yugoslav federation. The contemporary international political borders are the direct descendants of borders between former republics and provinces. During the Yugoslav period, the Serbs could demonstrate their political power in large regional context.

The political crisis in late 1980s (which began in 1981 by open Albanian rebellion in Kosovo) ended with the disintegration of Yugoslav federation. For the Serbs, this situation was by far the most disadvantageous among all former Yugoslav nations. For Serbs in Bosnia and Hercegovina, the proclamation of independency of this republic represented some kind of threat. In a series of local, but bloody wars on these territories, several particular para-states has been created, so called 'krajinas' in Croatia, while the 
Bosnia became two-level asymmetric federation after the Dayton agreement in 1995 . The Serbs are concentrated in their own entity of Republic of Srbska. In 2006, Montenegro, largely considered as a part of Serbia, decided for restoration of an old national tradition, and in February 2008 Kosovo proclaimed independency.

The paper is discussing the contemporary geopolitical position of Serbs in the Balkan region. The Serbs, living in two countries as a nation (or sub-nation), in a landlocked country with strong 'core', large minorities and large peripheries with numerous ethnic minorities and very large diaspora, as well as by bordering small, weak multiethnic territories, represent vulnerable nation. Demographically, the Serbs are comparable with Croatian, Bulgarian and Albanian ethnic corpus and are a bit smaller than their northern (Hungarian) and southern (Greek) partners. Such situation represents a geopolitical challenge for European enlargement vision, and for Serbs and Serbia, the decision between European integration and Russian political satellite.

(Translated by the author) 